
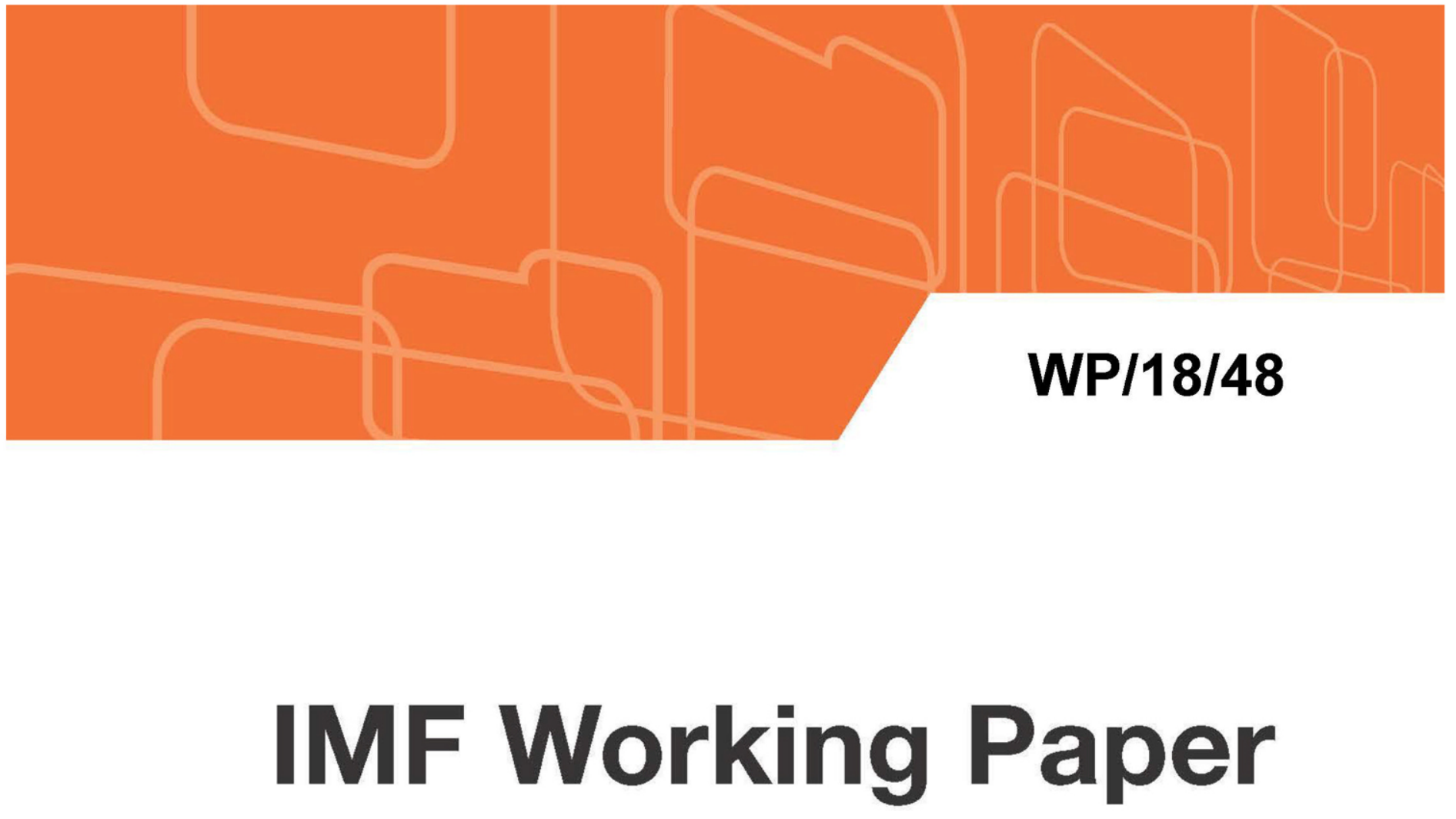

\title{
Forecasts in Times of Crises
}

by Theo S. Eicher, David J. Kuenzel, Chris Papageorgiou and Charis Christofides

IMF Working Papers describe research in progress by the author(s) and are published to elicit comments and to encourage debate. The views expressed in IMF Working Papers are those of the author(s) and do not necessarily represent the views of the IMF, its Executive Board, or IMF management. 


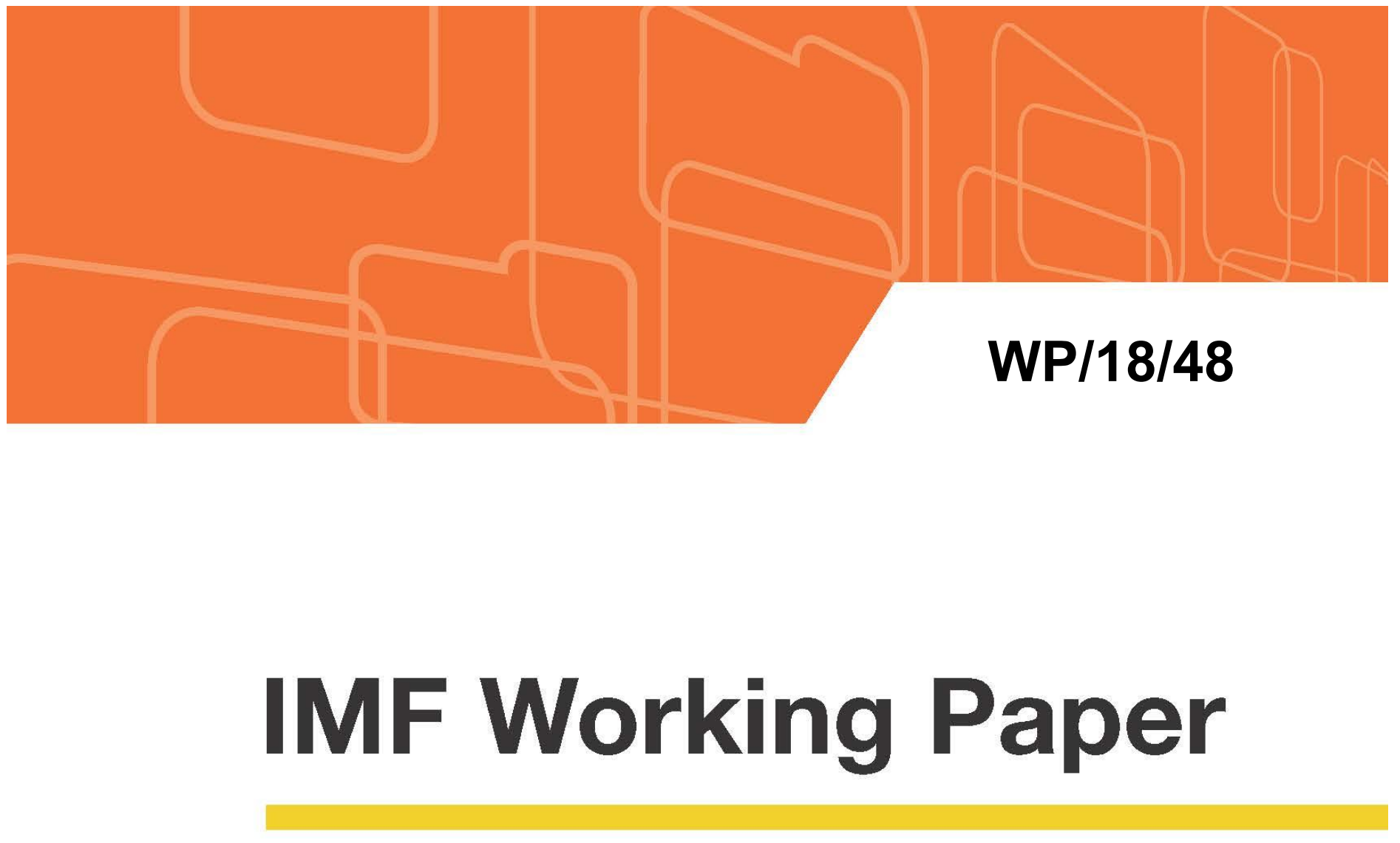

\section{Forecasts in Times of Crises}

by Theo S. Eicher, David J. Kuenzel, Chris Papageorgiou and Charis Christofides

IMF Working Papers describe research in progress by the author(s) and are published to elicit comments and to encourage debate. The views expressed in IMF Working Papers are those of the author(s) and do not necessarily represent the views of the IMF, its Executive Board, or IMF management.

$$
\text { I N T E R N A T I O N A L M O N E T A R Y F U N D }
$$




\title{
IMF Working Paper
}

\author{
Research Department
}

Forecasts in Times of Crises*

\section{Prepared by Theo S. Eicher ${ }^{\dagger}$, David J. Kuenzel, Chris Papageorgiou and Charis Christofides}

Authorized for distribution by Chris Papageorgiou

February 2018

\begin{abstract}
IMF Working Papers describe research in progress by the author(s) and are published to elicit comments and to encourage debate. The views expressed in IMF Working Papers are those of the author(s) and do not necessarily represent the views of the IMF, its Executive Board, or IMF management.
\end{abstract}

\begin{abstract}
Financial crises pose unique challenges for forecast accuracy. Using the IMF's Monitoring of Fund Arrangement (MONA) database, we conduct the most comprehensive evaluation of IMF forecasts to date for countries in times of crises. We examine 29 macroeconomic variables in terms of bias, efficiency, and information content to find that IMF forecasts add substantial informational value as they consistently outperform naive forecast approaches. However, we also document that there is room for improvement: two thirds of the key macroeconomic variables that we examine are forecast inefficiently and 6 variables (growth of nominal GDP, public investment, private investment, the current account, net transfers, and government expenditures) exhibit significant forecast bias. Forecasts for low-income countries are the main drivers of forecast bias and inefficiency, reflecting perhaps larger shocks and lower data quality. When we decompose the forecast errors into their sources, we find that forecast errors for private consumption growth are the key contributor to GDP growth forecast errors. Similarly, forecast errors for non-interest expenditure growth and tax revenue growth are crucial determinants of the forecast errors in the growth of fiscal budgets. Forecast errors for balance of payments growth are significantly influenced by forecast errors in goods import growth. The results highlight which macroeconomic aggregates require further attention in future forecast models for countries in crises.
\end{abstract}

JEL Classification Numbers: C53, C55, F30, F47

Keywords: Forecasting, IMF Programs, GDP Growth, Balance of Payments, Financial Accounts, Fiscal Accounts

Author's E-Mail Address: te@uw.edu, dkuenzel@,wesleyan.edu, cpapageorgiou@imf.org, cchristofides@imf.org

\footnotetext{
${ }^{*}$ We thank Andy Berg, Neil Ericsson, Prakash Loungani, two referees and the editor of this journal for their valuable comments. We are particularly grateful to Herman Stekler who served as the discussant of this paper at the conference on Forecasting Issues in Developing Economies held at the IMF in April 2017 for his detailed and constructive suggestions. Eicher thanks the IMF Institute for Capacity Development for its hospitality and financial support. Kuenzel thanks the IMF Research Department for its hospitality and financial support. Papageorgiou acknowledges support by the U.K.'s Department for International Development (DFID). The views expressed in this study are the sole responsibility of the authors and should not be attributed to the International Monetary Fund, its Executive Board, or its management.

${ }^{\dagger}$ Corresponding author: Theo Eicher, University of Washington
} 


\section{Contents}

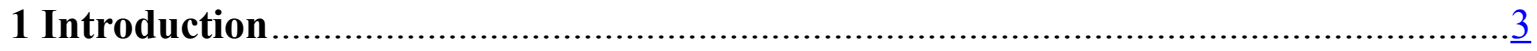

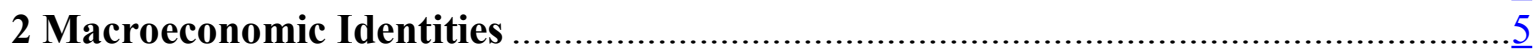

3 Methodology: Evaluating IMF Forecasts ………….......................................... 7

4 The Monitoring of Fund Arrangements (MONA) Dataset .........................................

5 IMF Forecast Errors: Decomposition and Determinants .......................................

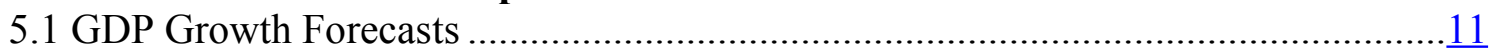

5.1.1 Efficiency and Unbiasedness .............................................................11

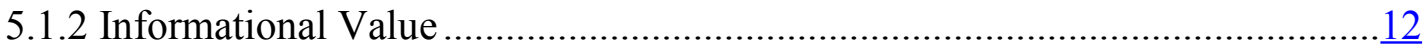

5.1.3 Forecast Error Contributions.....................................................................12

5.2 Balance of Payments Growth Forecasts ............................................................13

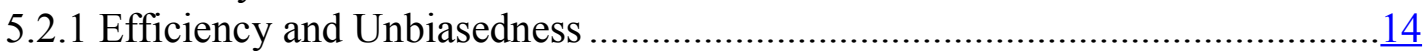

5.2.2 Informational Value ...........................................................................

5.2.3 Forecast Error Contributions.......................................................................15

5.3 Government Revenue and Expenditure Growth Forecasts ......................................16

5.3.1 Efficiency and Unbiasedness ................................................................

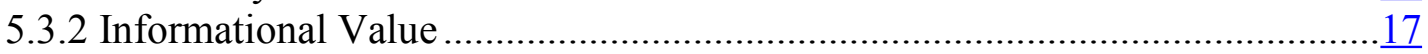

5.3.3 Forecast Error Contributions....................................................................17

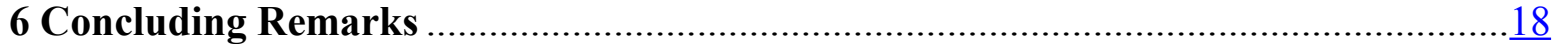

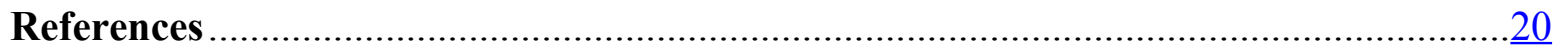

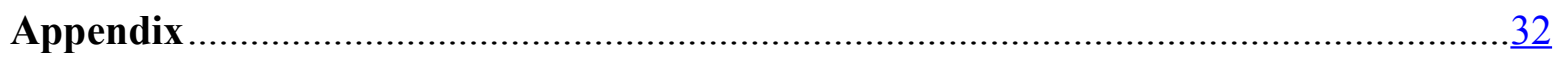

\section{List of Figures}

1 Forecasts versus Actual Changes..............................................................................

\section{List of Tables}

1 Mincer-Zarnowitz Regressions - GDP Growth........................................................22

2 Correct and Incorrect Forecasts of GDP and Its Subcomponent Growth Rates ...................23

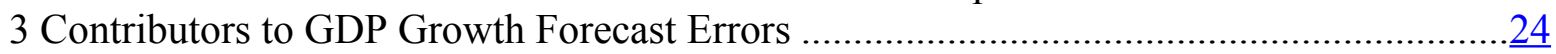

4a Mincer-Zarnowitz Regressions - Current Account Balance Growth ...............................25

4b Mincer-Zarnowitz Regressions - Financial Account Balance Growth ............................26

5a Correct and Incorrect Forecasts of Current Account and Its Subcomponent Growth Rates

$5 \mathrm{~b}$ Correct and Incorrect Forecasts of Financial Account and Its Subcomponent Growth Rates

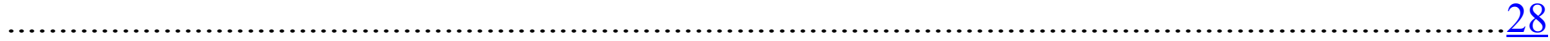

6 Contributors to Balance of Payments Forecast Errors ....................................................28

7a Mincer-Zarnowitz Regressions - Government Expenditure Growth ..............................29

7b Mincer-Zarnowitz Regressions - Government Revenue Growth.....................................30

8a Correct and Incorrect Forecasts of Gov. Expenditure and Its Subcomponent Growth Rates

$8 \mathrm{~b}$ Correct and Incorrect Forecasts of Gov. Revenue and Its Subcomponent Growth Rates

9 Contributors to Government Budget Growth Forecast Errors

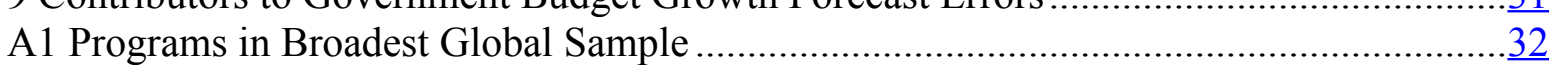


"A crisis is a terrible thing to waste."

- Paul Romer, 2004

\section{Introduction}

Forecast errors are exacerbated in times of crises, which has led critics to lament that economists "fundamentally overstate the reliability of their predictions" (Silver, 2012). If inaccurate economic forecasts in times of crises are indeed the rule and not the exception, the profession's ability to provide policy support is limited precisely at times when decisive policy guidance and action are most valued. We assess the accuracy of macroeconomic forecasts for countries which experienced economic crises so severe that they required financial support from the IMF - the lender of last resort - "to create breathing room as [countries] implement policies to restore economic stability and growth" (IMF, 2016a).

We assess forecasts using three metrics: (i) bias measures forecast deviations from realizations; (ii) efficiency measures if forecast errors were unpredictable (e.g., do forecasts contain all information available at the time of the forecast); and (iii) information content measures the informational value of forecasts relative to naive forecast models of directional changes. Forecasts are optimal when they are unbiased and efficient. Our work extends previous studies on crisis forecasts in four dimensions. First, we utilize the regression approaches of Mincer and Zarnowitz (1969) and Holden and Peel (1990) to examine forecast bias and efficiency to assess whether forecasts are optimal. Second, we examine whether IMF forecasts outperform naive forecast models of directional changes (see Merton, 1981, Henriksson and Merton, 1981, and Schnader and Stekler, 1990). Third, we evaluate IMF crisis forecasts for a much larger set of macroeconomic variables (29) and not only output and current account forecasts, which were the focal points of prior studies. Fourth, our paper is the first to decompose IMF forecast errors of macroeconomic aggregates (GDP, the balance of payments, and the fiscal accounts) to identify the subcomponents that require particular attention in future IMF forecasts (see, for instance, Sinclair and Stekler (2013) who highlight the importance of the quality of GDP component estimates for GDP forecasts).

Our main findings are threefold. First, we show that for nearly all variables IMF forecasts contain substantial informational value relative to naive forecasting models. Exceptions include

\footnotetext{
${ }^{1}$ Quotation attribution from Rosenthal (2009).
} 
the forecasts for inflation, government expenditure growth and net income growth, most likely because these variables tend to trend consistently in one direction for program countries.

Second, IMF growth forecasts of certain key macroeconomic aggregates exhibit biases and/or inefficiencies in the global sample of program countries. Nominal GDP growth is, on average, forecast too optimistically while current account growth and government expenditure growth are subject to downward bias. The latter may reflect the IMF's conservative approach to lending during times of crises. Growth forecasts of real GDP, prices, the financial account, and government revenue are found to be unbiased. We also determine that IMF forecasts of key indicators of crisis recovery, such as the growth in government expenditure, government revenue, prices, and reserves are efficient. When we examine forecasts for Low-Income Countries (LICs) and Non-Low-Income Countries (Non-LICs) separately, we find that IMF forecasts for LICs are substantially more biased and inefficient, which may be due to data and information challenges in these countries during times of crises.

Third, to identify their determinants, we decompose the forecast errors of macroeconomic aggregates into the contributions of their respective subcomponents based on accounting identities. GDP growth forecast errors are shown to be affected significantly by forecast errors in all GDP subcomponents (government, consumption, investment, net exports). Private consumption growth is, however, by far the most important contributor. Fiscal budget forecast errors are driven by forecast errors for non-interest/net-lending expenditures, tax/non-tax revenues, and grants. With one exception (goods imports), balance of payments forecast errors cannot be linked to the forecast errors in any of its subcomponents.

The existing literature on evaluations of crisis forecasts focuses mainly on bias and program conditionality. Ghosh et al. (2005) examine the bias of macroeconomic forecasts in program countries to find no systematic biases. Their analysis uses an earlier version of the MONA dataset and the authors neither track the sources of forecast errors nor forecast efficiency. Baqir et al. (2005) analyze IMF forecasts for GDP growth, inflation, the current account and the fiscal balance to find systematic forecast bias for growth and inflation without identifying the underlying causes. Luna (2014) finds that IMF crisis forecasts for GDP growth and inflation are upward biased for program countries with "exceptional access" to IMF resources, while current account and government budget forecasts exhibit downward bias 
(without identifying the sources of the bias). Atoyan et al. (2004) and Atoyan and Conway (2011) also find substantial bias in fiscal and current account forecasts, and identify the IMF forecast model and poor measurement of initial conditions as major contributors to forecast bias in crisis countries. ${ }^{2}$

The remainder of the paper is structured as follows. Section 2 lays out a set of identities used to forecast the growth rates of macroeconomic aggregates based on their individual subcomponents. Section 3 presents our approach to evaluating IMF forecasts for countries during times of crises. Section 4 discusses the data, and Section 5 reports our main results. Section 6 concludes and highlights the policy relevance of our findings.

\section{Macroeconomic Identities}

Our forecast models are motivated by macroeconomic identities. Specifically, we focus below on macroeconomic identities that are fundamental for structuring and assessing the success of IMF programs: aggregate demand, the balance of payments, and fiscal accounts. Our general focus in this paper is on forecasting the growth rates of nominal variables, since deflators are often nonuniform across countries, which would introduce confounding errors. Examining growth rates also allows us to circumvent potential issues relating to changes in currency denominations or unit changes that are frequently encountered during times of crisis.

We start with aggregate demand. According to IMF (2007), the national income identity for an open economy decomposes nominal GDP, $Y$, into final private and public consumption $\left(C_{p}, C_{g}\right)$, private and public investment $\left(I_{p}, I_{g}\right)$, and imports and exports $(M, X)$ :

$$
Y=C_{p}+C_{g}+I_{p}+I_{g}+X-M
$$

Totally differentiating (1) yields:

$$
y=\sigma_{y, c_{p}} c_{p}+\sigma_{y, c_{g}} c_{g}+\sigma_{y, i_{p}} i_{p}+\sigma_{y, i_{g}} i_{g}+\sigma_{y, x} x-\sigma_{y, m} m
$$

\footnotetext{
${ }^{2}$ Other earlier studies of IMF forecast performance in crisis countries have a much narrower focus in terms of: (i) included variables, (ii) samples of included program countries, and (iii) time periods under consideration. See, e.g., Goldstein (1986), Musso and Phillips (2002), and Golosov and King (2002). Several studies also consider whether early data releases provide sufficiently accurate information about the state of the economy, especially prior to and during recessions. See, e.g., Dynan and Elmendorf (2001), Joutz and Stekler (1998), McNees (1986), and Swanson and van Dijk (2006).
} 
where small letters indicate growth rates and $\sigma_{i, j}$ represent elasticities. For instance, $\sigma_{y, c_{p}}$ measures the percentage change in GDP growth due to a percentage change in private consumption growth.

Next, we consider the balance of payments (BOP), a variable of key interest as most IMF programs take place in countries that face foreign exchange reserve shortages generated by current account or financial flow deficits. We investigate the current and financial accounts separately to capture the potentially distinct impacts of international income and capital transactions. Using the IMF's (2015) decomposition of the current account, we obtain the following growth rate identity:

$$
c a=\sigma_{c a, x_{g}} x_{g}+\sigma_{c a, x_{s}} x_{s}-\sigma_{c a, m_{g}} m_{g}-\sigma_{c a, m_{s}} m_{s}+\sigma_{c a, n i} n i+\sigma_{c a, n t} n t
$$

where $c a$ is the current account growth rate, $x_{g}$ and $x_{s}$ are the growth of goods and services exports, respectively, and $m_{g}$ and $m_{s}$ are the corresponding measures for imports. $n i$ and $n t$ capture the growth in net income and net transfers of a country with the rest of the world.

Similarly, following again the IMF's (2009) official definition, the growth in the financial account $(f a)$ is given by:

$$
f a=\sigma_{f a, f d i} f d i+\sigma_{f a, p i} p i+\sigma_{f a, r e s} r e s+\sigma_{f a, o t} \text { ot },
$$

which is decomposed into the contributions of the growth rates in net foreign direct investment (fdi), net portfolio investment ( $p i)$, reserve assets (res), and other investment (ot).

Finally, as government budgets are a crucial element in evaluating the sustainability of IMF programs and countries' recoveries, we consider the IMF's (2014) official breakdown for both government expenditures and revenues:

$$
\begin{aligned}
& g x=\sigma_{g x, \text { int }} \text { int }+\sigma_{g x, n \text { int }} n \text { int }+\sigma_{g x, c a p} c a p \\
& g r=\sigma_{g r, t a x} t a x+\sigma_{g r, n t a x} n t a x+\sigma_{g r, g r t} g r t,
\end{aligned}
$$

where government expenditure growth $(g x)$ is decomposed into the growth rates of interest expenditures (int), non-interest expenditures (nint), and outlays on capital expenditure and net 
lending (cap). Similarly, government revenue growth $(g r)$ can be decomposed into the growth rates of tax revenue (tax), non-tax revenue (ntax), and grants $(g r t)$.

Having discussed the growth rate decompositions of aggregate demand, the balance of payments, and fiscal revenues and expenditures, the next section lays out how we can evaluate IMF forecasts of these macroeconomic identities.

\section{Methodology: Evaluating IMF Forecasts}

To assess the accuracy of IMF forecasts in program countries, we rely on three complementary approaches frequently employed in the literature: Mincer-Zarnowitz regressions, Holden-Peel tests and Merton-Henriksson type timing tests. The Mincer-Zarnowitz regressions link actual $\left(\mathrm{A}_{\mathrm{i}}\right)$ and forecast $\left(\mathrm{F}_{\mathrm{i}, \mathrm{p}}\right)$ values for country $i$ as follows: ${ }^{3}$

$$
A_{i}=\alpha+\beta F_{i, p}+\theta X_{i, p}+\varepsilon_{i}
$$

where in our context the forecast is conditional on information available at the time of the initiation of the IMF program $p . X$ is a vector of additional controls that can be introduced to address omitted variable bias. An efficient forecast should generate coefficient values of $\alpha=0$ and $\beta=1$, respectively. Therefore, we implement below an F-test of this joint null hypothesis, with rejection indicating that forecasts are inefficient. In the regressions below, the $X$ vector includes continental dummies (America, Africa, Asia) and a binary Financial Crisis indicator (Crisis08) to control for regional- and crisis-specific effects on forecasts.

Holden and Peel (1990) show that failing to reject the Mincer-Zarnowitz F-test constitutes a sufficient but not a necessary condition for the unbiasedness of forecasts. To test for unbiasedness, we follow Holden and Peel and implement a t-test for the hypothesis that $\gamma=0$ in the following regression:

$$
A_{i}-F_{i, p}=\gamma+\lambda X_{i, p}+\eta_{i}
$$

A rejection of the Holden-Peel test indicates that forecasts are biased.

\footnotetext{
${ }^{3}$ For applications of this methodology, see, for example, Sinclair et al. (2008, 2010).
} 
The Merton-Henriksson timing tests were originally designed by Merton (1981) and Henriksson and Merton (1981) to examine whether market-timing forecasts of asset returns add informational value. This methodology was adapted to macroeconomic variables by Schnader and Stekler (1990) who introduced a 2 x 2 contingency table to determine whether the forecasts are independent of the observed events. Figure 1 below illustrates the general idea, where N1 (N2) captures the number of observed positive (zero or negative) changes, while n1 (n2) is the number of correct (incorrect) positive forecasts. To evaluate the IMF's performance in forecasting an economic variable, we consider how frequently the direction of the actual change conforms with the IMF forecast. Using a $\chi^{2}$ test, we can formally test the null hypothesis that the observed events are independent of the forecasts. ${ }^{4}$ In case of a rejection, the forecasts contain informational value.

Figure 1: Forecasts versus Actual Changes

\begin{tabular}{|c||c|c|c|}
\hline & Actual $>\mathbf{0}$ & Actual $\leq \mathbf{0}$ & Total \\
\hline Forecast $>\mathbf{0}$ & $n 1$ & $n 2$ & $\boldsymbol{n}$ \\
\hline Forecast $\leq \mathbf{0}$ & $N 1-n 1$ & $N 2-n 2$ & $\boldsymbol{N}-\boldsymbol{n}$ \\
\hline Total & $\mathbf{N 1}$ & $\mathbf{N} 2$ & $\boldsymbol{N}$ \\
\hline
\end{tabular}

In a fourth step, we examine the sources of IMF forecast errors for key variables in crisis countries. Specifically, we consider to what extent forecast errors in subcomponents are responsible for forecast errors of the different macroeconomic aggregates outlined above. To that end, we regress the forecast error of our variables of interest on the left-hand side of the above identities, e.g., GDP growth, on the forecast errors of our explanatory variables on the right-hand side of the respective identities. In particular, for $S$ explanatory variables, we estimate: ${ }^{5}$

\footnotetext{
${ }^{4}$ Schnader and Stekler (1990) provide the test statistic for the $2 \times 2$ contingency table: $\sum_{i} \sum_{j}\left(N_{i j}-N p_{i j}\right)^{2} / N p_{i j}$ where $N_{i j}$ is the frequency in the $i-j$ th cell and $N p_{i j}$ is the expected frequency.

${ }^{5}$ We do not attempt to identify with our regression framework the elasticities in the macroeconomic identities laid out in Section 2. We simply estimate the contributions of the different subcomponent forecast errors to the forecast error of the respective aggregate variable. Note that equation (9) could also be estimated in absolute error terms, which might, however, exaggerate the imprecision of IMF crisis forecasts. These results are available upon request.
} 


$$
\hat{y}_{i}-y_{i}=\alpha+\sum_{j=1}^{S} \beta_{j}\left(\hat{x}_{i j}-x_{i j}\right)+\varepsilon_{i},
$$

where $\hat{x}_{i j}$ and $\hat{y}_{i}$ are the forecast growth rates of variables $x_{j}$ and $y$ in country $i$ between years $t-1$ and $t$, while $x_{i j}$ and $y_{i}$ are the realized growth rates over the same time span. The coefficients in (9) have a straightforward interpretation: A 1\% increase in the average forecast error of an explanatory variable $x_{j}$ causes a $\beta_{j} \%$ change in the average forecast error of the macroeconomic aggregate $y$.

\section{The Monitoring of Fund Arrangements (MONA) Dataset}

We obtain all our data on forecasts and actual realizations of macroeconomic indicators in crisis countries from the IMF's Monitoring of Fund Arrangements dataset (MONA, IMF 2016b). While the original dataset covers 238 crisis programs since 2002, the data availability for even the broadest macroeconomic identities is limited to 156 programs in 84 countries (see Table A1). ${ }^{6}$ Observations are lost due to reporting, measurement and validation discrepancies. ${ }^{7}$ We also exclude forecast errors that exceed the respective variable means by four standard deviations to ensure that our results are not driven by extreme outliers that may well be data entry errors.

To obtain data on forecasts and actual values from MONA, we proceed as follows for each given variable. Denote $t$ as the year when an IMF program is approved. At $t$, IMF country economists enter the respective program data into the MONA database for the years $t-3, t-2, t-1$, $t, t+1, t+2, t+3$, and $t+4$. In this sequence, $t$ is the forecast for the current, first program year while $t-3, t-2$, and $t-1$ are historical data (subject to revisions) and $t+1, t+2, t+3$, and $t+4$ are 1 -, 2-, 3-, and 4-year ahead forecasts, respectively. ${ }^{8}$ In this paper, we examine the accuracy of the IMF forecast for year $t$ to maximize the number of observations in the sample (the number of observations declines substantially with forecast horizon in MONA). For each country, we

\footnotetext{
${ }^{6}$ While several countries in the sample have been subject to more than one IMF program, we treat these observations as independent since the programs are subject to different conditions and occur in separate years.

${ }^{7}$ An older version of the MONA crisis dataset is available, covering countries from 1993 to 2003. However, the older MONA dataset is not compatible in terms of variable descriptions and no harmonization exists; hence, we focus on post 2002 data.

${ }^{8}$ Strictly speaking, forecasts for the current period can also be referred to as "nowcasts," which Castle et al. (forthcoming) define as "forecasts of the current or recent aggregate state of an economy." The IMF refers to the MONA period $t$ estimates as "forecasts" and we follow this tradition in our analysis below.
} 
compare the growth rates of our variables of interest from $t-1$ to $t$ which have been entered during the first review (at time $t$ when the program is approved) with the realized growth rate from $t-1$ to $t$ that is reported in the last review (when the program is completed). To make sure that observations from the last review represent actual realized data, we only include programs running longer than 18 months in our sample. ${ }^{9}$ Using an 18-months threshold also offers the advantage of leaving ample time for data revisions so that actual variable realizations are comparable across IMF programs. Lastly, we should also note that although all programs are initiated at different points throughout the year (see Table A1), we do not find any evidence that the forecast errors systematically differ across programs due to these timing differences. ${ }^{10}$ This result might be driven by the predictability of the target variables; see Lahiri and Sheng (2010) for a detailed discussion.

\section{IMF Forecast Errors: Decomposition and Determinants}

In this section, we evaluate IMF forecast accuracy for key macroeconomic identities and their subcomponents in crisis countries. Following the sequence of key macroeconomic identities discussed in Section 2, we start by examining GDP growth forecasts, and then continue with an analysis of the current and financial accounts before considering fiscal revenues and expenditures. For each macroeconomic identity, we first employ the Mincer-Zarnowitz and Holden-Peel regressions as shown in equations (7) and (8), and then apply the MertonHenriksson timing tests based on the approach outlined in Figure 1. In the final step, we estimate the empirical forecast error model as specified in equation (9). These regressions allow us to deduce to what extent forecast errors of our macroeconomic aggregates of interest can be traced back to individual subcomponents that serve as key inputs in the forecast. We also report in all cases separate results for both low-income countries (LICs) and more advanced economies (NonLICs) to examine whether the IMF forecast errors are driven by different subsamples.

\footnotetext{
${ }^{9}$ The 18 months refer to the review period, not the period of actual credit outstanding.

${ }^{10}$ When breaking the forecasts for year $t$ into 12 subsamples, each identified by the month in which the forecast was undertaken, we find substantial variation in the forecasts errors. However, these fluctuations are not correlated with the timing of the forecasts. Forecasts generated later in the year are not necessarily better than earlier forecasts. For example, in the case of nominal GDP, the October and November forecast errors for $t$ are larger than February's. Aside from eyeballing, we also use formal t-tests to examine whether monthly, quarterly or semi-annual mean forecast errors are identical to the annual sample's counterpart. In all cases, this null hypothesis cannot be rejected at the $1 \%, 5 \%$ and $10 \%$ percent levels of statistical significance. We thus do not report separate results for monthly, quarterly, or semi-annual subsamples.
} 


\subsection{GDP Growth Forecasts}

\subsubsection{Efficiency and Unbiasedness}

The results from the Mincer-Zarnowitz regressions are reported in Table 1. The columns collect results for each variable included in the national income accounts identity, plus real GDP and average prices (based on the CPI). The upper panel reports full-sample results, while the middle and lower panels show estimates for the LIC and Non-LIC subsamples. The bottom of each panel reports results for the joint F-test of forecast efficiency ( $\alpha=0$ and $\beta=1)$ and the HoldenPeel t-test of unbiasedness. Note that throughout the table significance levels are only indicated for the F-test and the Holden-Peel test but not for the individual coefficient estimates.

In the full sample, real GDP forecasts are found to be unbiased but inefficient (the joint F-test is rejected at the 1 percent level indicating inefficient forecasts while the Holden-Peel ttest cannot reject the null hypothesis of unbiasedness). The inefficiency of real GDP forecasts is completely driven by the LIC sample. However, this finding does not carry over to nominal GDP and to average prices, which are both key inputs in the IMF's program design. Forecasts of average price growth are found to be both unbiased and efficient irrespective of the considered sample. The full-sample forecasts of nominal GDP growth, on the other hand, are both inefficient and biased as both the F-test and the Holden-Peel t-test are rejected at the 5 percent level of statistical significance. The full-sample intercept estimate and the negative Holden-Peel $\mathrm{t}$-statistic indicate that the IMF overestimates, on average, nominal GDP growth. Interestingly, this result seems to be mostly driven by the Non-LIC sample while nominal GDP growth forecasts for LIC countries are both unbiased and efficient. ${ }^{11}$

With regard to the GDP subcomponents, two interesting results emerge. First, except for private consumption, the IMF forecasts are all significantly biased and/or inefficient in the full sample of crisis countries. Second, the biased and/or inefficient forecasts of the different GDP subcomponents, except for public consumption and public investment growth, are driven entirely by the LIC sample. In the Non-LIC sample, we only reject the null hypothesis of efficiency for

\footnotetext{
11 Note that the bias in nominal GDP growth forecasts does not necessarily imply a bias in real GDP growth forecasts as the latter can be interpreted as an average of the nominal GDP growth and inflation forecasts. Palm and Zellner (1992) point out that an average of forecasts will result in a significant reduction in variance and bias through averaging out individual biases in the subcomponent forecasts.
} 
the public consumption and public investment components of GDP, while also detecting a bias for the latter.

\subsubsection{Informational Value}

Table 2 provides the Merton-Henriksson test results of informational value added by the IMF forecasts for GDP and its subcomponents (plus real GDP and average prices). For each variable, the test determines whether the IMF forecasts perform better than a naive model that always suggests a positive or negative forecast. The $\chi^{2}$-statistics for the full sample in the upper panel reject the null hypothesis (at least at the 5 percent level) of independent forecasts and actuals for all variables except average prices. That is, IMF forecasts for most national income components contain significant informational value. This pattern is broadly mirrored by the Non-LIC sample in the lower panel of Table $2 .{ }^{12}$ In contrast, the results for the LIC sample in the middle panel of Table 2 are more mixed. As in the full and LIC samples, we find that IMF forecasts for the growth rates of real GDP, nominal GDP, imports, and public investment all contain statistically significant informational value. However, forecasts of the remaining subcomponents of GDP as well as average price growth do not significantly outperform a naive forecasting model.

\subsubsection{Forecast Error Contributors}

Finally, we explore to what degree the forecast errors in the growth rates of the different GDP subcomponents contribute to forecast errors of GDP growth itself. Addressing this question can provide valuable insights for future IMF forecasts. In particular, we can identify variables for which improvements in forecast accuracy would benefit the precision of GDP growth forecasts the most. Table 3 presents regression results of the forecast error of GDP growth as a function of all explanatory variables motivated by the national income identity. The full sample results in column $3 \mathrm{a}$ indicate that forecast errors in every single subcomponent are significant predictors of IMF forecast errors in GDP growth. ${ }^{13}$ In terms of magnitudes, forecast errors in the growth rates of private consumption, imports and exports contribute the most to forecast errors in GDP growth. The LIC subsample results in column $3 \mathrm{~b}$ mirror the full-sample estimates quite closely. Interestingly, for the Non-LICs subsample in column 3c, we observe that the role of forecast

\footnotetext{
12 Note that no test statistic can be computed for the growth rate of average prices in the Non-LIC case as the IMF did not forecast any deflationary periods for this subsample.

13 One caveat to the interpretation of these results is that some of the subcomponents could be residuals in the IMF macro prediction framework. Hence, we cannot rule out that forecast errors in the subcomponents might be driven to some extent by forecast errors in nominal GDP growth itself.
} 
errors in private consumption growth is somewhat subdued compared to LICs, while forecast errors in import and export growth take a more prominent role. At the same time, forecast errors in public consumption and investment growth play no role in explaining Non-LIC forecast errors in GDP growth.

Overall, the analysis in this part reveals somewhat mixed results for IMF forecasts of GDP growth and its subcomponents. Problems identified in the earlier literature regarding the bias and/or inefficiency of GDP forecasts are confirmed, although inflation forecasts are in general not subject to the same caveat. As evident from the Mincer-Zarnowitz regressions and Holden-Peel tests, bias and/or inefficiency in IMF growth forecasts of real GDP and most GDP subcomponents are driven by the LIC sample. ${ }^{14}$ Nonetheless, the Merton-Henriksson test results suggest that, in general, IMF forecasts possess significant informational value, although the evidence is again a lot more mixed for the LIC sample. Finally, the forecast error regression analysis reveals that forecast errors in all subcomponents contribute to forecast errors in aggregate GDP growth in the full sample, with private consumption, imports and exports taking the lead both in terms of statistical and economic significance.

\subsection{Balance of Payments Growth Forecasts}

IMF forecasts for the balance of payments (BOP) in program countries are crucial for at least two reasons. First, the BOP forecasts are key in determining financial assistance and program design. Second, they are also subsequently used to assess countries' progress in closing BOP gaps by increasing buffers through the reduction in current and financial account deficits as well as increases in international reserves. In this section, we therefore assess the IMF's forecasts of both the current account and the financial account in program countries. As outlined in the identities above, the growth rate of the current account can be decomposed into six subcomponents: goods import and export growth, services import and export growth, as well as the growth rates of net transfers and net income. Similarly, financial account growth can be broken down into the growth rates of net direct investment, reserve assets, net portfolio investment, and "other investments."

\footnotetext{
${ }^{14}$ These results could be driven in part by the data constraints under which LICs operate. Moreover, crisis countries face a much more uncertain economic outlook as well as unpredictable policy choices. Blanchard and Leigh (2013), for instance, note that fiscal multipliers are amplified during crises, leading to underestimates of the impact of fiscal shocks on economic growth.
} 


\subsubsection{Efficiency and Unbiasedness}

Table 4a reports the Mincer-Zarnowitz regression and Holden-Peel test results for the growth rates of the current account and all its subcomponents. For the full sample in the upper panel, we observe that the joint F-test of efficient IMF forecasts is rejected at least at the 10 percent level for all current account variables except goods export growth. At the same time, however, the Holden-Peel t-tests indicate that the null hypothesis of unbiasedness is only rejected for two variables: the current account and net transfers. Similar to the GDP growth forecasts in the previous section, these results are again mainly driven by the LIC sample, where all current account forecast variables are found to suffer significantly (at least at the 5 percent level) from inefficiency and two subcomponents (goods imports and services imports) are forecast with significant bias. While in the Non-LIC sample the null hypothesis of forecast efficiency is also rejected for the overall current account, the same is true for only two of its subcomponents, net transfers and net income. In the Non-LIC sample, we also detect only one variable that is estimated with significant bias: the growth rate of net transfers.

The upper panel of Table $4 \mathrm{~b}$ reports the full-sample Mincer-Zarnowitz regressions and Holden-Peel t-tests for the financial account. We reject the null hypothesis of an efficient forecast (at the 1 percent significance level) for three subcomponents: growth in net direct investment, growth in other investment, and growth in net portfolio investment. At the same time, focusing on the Holden-Peel t-test, there is no evidence for biased forecasts of the financial account and any of its subcomponents. The LIC sample results in the middle panel of Table $4 \mathrm{~b}$ indicate inefficient and/or biased forecasts for all four subcomponents of the financial account. The joint F-test and the Holden-Peel test reject the null hypotheses of efficient and unbiased forecasts throughout at least at the 5 percent level of statistical significance, except in the case of the "other investments" component for which no bias can be detected. Interestingly, the forecasts of aggregate financial account growth itself are neither biased nor inefficient, suggesting that perhaps the subcomponent errors cancel each other out in this case. The Non-LIC sample results in the bottom panel are more similar to the full sample, except that the financial account forecasts are now found to be inefficient while the same does not hold anymore for net direct investment. Hence, similar to the case of GDP and its subcomponents, the Non-LIC forecasts for the current and financial accounts tend to be more efficient and less biased than their LIC counterparts. 


\subsubsection{Informational Value}

Turning to the Merton-Henriksson tests in Table 5a, the full-sample results for the current account and its subcomponents show that all forecasts, except for net income, contain statistically significant informational value. We observe a similar pattern for the LIC subsample in the middle panel of Table 5a, except that the forecasts of net income growth now manage to outpace significantly a naive forecasting model. At the same time, IMF forecasts of net transfer growth in LICs have become statistically indistinguishable from a model that forecasts throughout either positive or negative growth. In the Non-LIC sample in the bottom panel of Table 5a, nearly the exact same results pattern emerges, with one exception. Both net transfers and net income growth forecasts are not providing any statistically significant informational value relative to a naive forecasting model in the Non-LIC sample.

The Merton-Henriksson tests for the financial account and its subcomponents in Table 5b stand in stark contrast to our prior findings for the GDP and current account identities. Considering the full-sample results in the upper panel, only IMF forecasts of financial account growth itself and of net direct investment growth add any significant informational value. In fact, except for financial account growth in the Non-LIC group, none of the remaining variable forecasts can significantly outperform a naive forecasting model in any of the subsamples. This finding suggests that the IMF's forecasting approach for the financial account and its subcomponents in crisis countries is in need of improvement.

\subsubsection{Forecast Error Contributors}

In the next step, Table 6 seeks to identify whether the forecast errors in current and financial account growth are driven by forecast errors in their respective subcomponents. Using the regression approach outlined in equation (9), panel A reports results for the current account, while panel B focuses on the financial account. Remarkably, of all explanatory variables only one regressor in the full sample, the forecast error in the growth rate of goods imports, can be linked to aggregate balance of payments forecast errors. These results are without doubt a consequence of the immense variances from which the growth rate forecasts for the current and financial accounts as well as their subcomponents suffer (summary statistics are available upon request). Importantly, these findings further reinforce the potential need for the IMF to adjust its forecasting approach for balance of payments subcomponents in program countries. 


\subsection{Government Revenue and Expenditure Growth Forecasts}

Finally, we consider the IMF's forecast accuracy for the growth of government revenues and government expenditures in crisis countries. As laid out above in the government finance identities, three subcomponents drive government expenditure growth: the respective growth rates of interest, non-interest and capital expenditures. Government revenue growth, on the other hand, can be decomposed into the growth rates of grants, tax revenues and non-tax revenues. We start again by assessing the IMF forecast errors for both government expenditure and revenue growth via Mincer-Zarnowitz regressions and Holden-Peel tests, and then conduct an evaluation of informational value added using the Merton-Henriksson approach. Subsequently, we examine to what extent forecast errors in the respective subcomponents drive forecast errors in the aggregate expenditure and revenue variables in crisis countries.

\subsubsection{Efficiency and Unbiasedness}

Table 7a reports the Mincer-Zarnowitz regressions for government expenditure growth and its subcomponents as well as the Holden-Peel t-test results. The joint F-test of efficient government expenditure forecasts cannot be rejected for the full sample in the upper panel. In fact, of all subcomponents, only interest expenditure growth forecasts are found to be inefficient. With regard to the hypothesis of unbiasedness, the Holden-Peel tests only show evidence for significant bias in the forecasts for aggregate government expenditure growth. The results for the LIC sample in the lower panel are mostly similar, except that aggregate government expenditure growth is now found to be unbiased as well and the capital expenditure category forecasts are inefficient. Note that we do not report separate results for the Non-LIC sample as there are only 5 countries in the government expenditure sample that meet this criterion.

Table $7 \mathrm{~b}$ considers Mincer-Zarnowitz regressions and Holden-Peel t-tests of government revenue growth and its subcomponents. For the full sample in the upper panel, the joint F-test indicates that the forecast growth rates for two subcomponents suffer from inefficiency: grants and non-tax revenue. However, the Holden-Peel tests show that neither aggregate government revenue nor any of its subcomponent suffer from bias. In contrast, the LIC sample results in the lower panel of Table $7 \mathrm{~b}$ are biased and inefficient throughout for both aggregate government revenue growth and all of its subcomponents. Hence, the full sample results seem to be mostly driven by the presence of Non-LIC programs. Note that we choose again to not report separate 
results for the Non-LIC sample due to the small number of 12 observations, which would not allow for reliable statistical inference.

\subsubsection{Informational Value}

Two results emerge when turning to the Merton-Henriksson tests for government expenditure growth and its subcomponents in Table 8a. First, the full sample results in the upper panel indicate that IMF forecasts for aggregate government expenditure growth do not contain any statistically significant informational value. On the upside, however, the IMF forecasts for all government expenditure subcomponents are significantly outperforming naive forecasting models. Second, the full sample estimates are entirely driven by LICs as illustrated by the considerable overlap in results between the upper and lower panels in Table 8a. Note that we omit again the results for the Non-LIC sample due to the limited number of observations. When evaluating forecasts for government revenue growth and its subcomponents in Table 8b, we find instead much stronger evidence that IMF forecasts contain valuable information. Specifically, when focusing on the full and the LIC samples (the Non-LIC results are again not reported due to only 12 observations), the forecasts for all variables significantly outperform naive forecasting models in both cases.

\subsubsection{Forecast Error Contributors}

In Table 9, we examine again in a more structured way the forecast error contributions of the respective government expenditure and revenue subcomponents. Employing the error regression approach in equation (9), panel A presents the results with the forecast errors for government expenditure growth as dependent variable. Panel B shows the respective estimates for forecast errors in government revenue growth.

The estimates in panel A reveal that IMF forecast errors in the growth rates of noninterest expenditures as well as capital expenditures and net lending are both significant drivers of forecast errors in aggregate government expenditure growth. We also observe very similar estimates in the LIC sample. In contrast, the full-sample government revenue regression in panel B of Table 9 shows that forecast errors in all subcomponents are significant contributors to aggregate forecast errors. The coefficient magnitudes suggest, however, that forecast errors in tax revenue growth have by far the greatest economic impact. As taxes are the primary government revenue source in most countries, it is not surprising that forecast errors in this 
variable carry substantial weight. At the same time, forecast errors in the growth of non-tax revenue do not matter for aggregate revenue forecast errors in LICs. Otherwise, the LIC results closely resemble the estimates for the full sample.

Overall, while several forecasts of fiscal aggregates and their subcomponents, in particular on the government revenue side, are biased and/or inefficient, the IMF forecasts still add informational value. At the same time, our analysis shows that forecast errors for most subcomponents also feed into forecast errors of aggregate fiscal accounts in crisis countries. Increasing the accuracy in fiscal subcomponent forecasts would therefore help the IMF to improve forecasts of aggregate fiscal balances in crisis countries more generally.

\section{Concluding Remarks}

We examine IMF forecasts for countries that experience severe economic crises and require access to IMF lending facilities. To evaluate forecasts, we assess the bias, efficiency, and information content of IMF forecasts. Based on accounting identities we then disentangle the contributions of subcomponents' forecast errors to forecast errors of key macroeconomic aggregates.

IMF forecasts are shown to be informative, as the forecasts of most aggregate macroeconomic variables outperform naive forecasting approaches. We also find that IMF forecasts are unbiased (i.e., there are no significant deviations of forecasts from realizations) and efficient (i.e., all information available at the time of forecasts is used) for government revenue growth, inflation, and reserve asset growth. Perhaps more importantly, we provide evidence that real GDP growth forecasts are unbiased and government expenditure growth forecasts are efficient. These variables are, after all, the most important welfare proxies as countries recover from crises.

That said, we find that lack of efficiency is the weakest link in IMF forecasts. Moreover,

our analysis uncovers significant heterogeneity in the accuracy of forecasts for low-income countries (LICs) and Non-LICs. In most cases, we can trace the biases/inefficiencies in the global sample directly to forecast errors originating in LICs. Our analysis of IMF forecasts, in particular for nominal GDP and the balance of payments, also reveals scope for improvements. 
Incorporating information from data revisions and adjustments in forecast horizons could provide helpful guidance for increasing the accuracy of future IMF forecasts during times of crises. We hope that our work can serve as a starting point of further inquiry into this important issue. 


\section{References}

Atoyan, Rouben, Patrick Conway, Marcelo Selowsky and Tsidi Tsikata, 2004. "Macroeconomic Adjustments in IMF-supported Programs: Projections and Reality," IEO Background Paper BP/04/2, International Monetary Fund.

Atoyan, Rouben and Patrick Conway, 2011. "Projecting Macroeconomic Outcomes: Evidence from the IMF," Review of International Organizations, 6 (September), 415-441.

Baqir, Reza, Rodney Ramcharan, and Ratna Sahay, 2005. "IMF Programs and Growth: Is Optimism Defensible?" IMF Staff Papers, 52 (2), 260-286.

Blanchard, Olivier and Daniel Leigh, 2013. "Growth Forecast Errors and Fiscal Multipliers," IMF Working Paper WP/13/1, International Monetary Fund.

Castle, Jennifer L., David F. Hendry and Oleg I. Kitov, forthcoming. "Forecasting and Nowcasting Macroeconomic Variables: A Methodological Overview," Handbook on Rapid Estimates.

Dynan, Karen E. and Douglas W. Elmendorf, 2001. "Do Provisional Estimates of Output Miss Economic Turning Points?” FRB FEDS Discussion Paper No. 2001-52.

Ghosh, Atish, Charis Christofides, Jun Kim, Laura Papi, Uma Ramakrishnan, Alun Thomas and Juan Zalduendo, 2005. "The Design of IMF-Supported Programs," Occasional Paper 241, International Monetary Fund.

Goldstein, Morris, 1986. "The Global Effects of Fund-supported Adjustment Programs," IMF Occasional Paper 42, International Monetary Fund.

Golosov, Mikhail and John King, 2002. "Tax Revenue Forecasts in IMF-supported Programs," IMF Working Paper WP/02/236.

Henriksson, Roy D. and Robert C. Merton, 1981. "On Market Timing and Investment Performance. II. Statistical Procedures for Evaluating Forecasting Skills," Journal of Business, 54 (4), 513-533.

Holden, Ken and David A. Peel, 1990. "On Testing for Unbiasedness and Efficiency of Forecasts," The Manchester School, 58 (2), 120-127.

IMF, 2007. "The System of Macroeconomic Accounts Statistics: An Overview," Pamphlet Series, No. 56, Washington, D.C. https://www.imf.org/external/pubs/ft/pam/pam56/pam56.pdf.

IMF, 2009. "Balance of Payments and International Investment Position Manual," Sixth Edition (BPM6), Washington, D.C. https://www.imf.org/external/pubs/ft/bop/2007/pdf/bpm6.pdf.

IMF, 2014. "Government Finance Statistics Manual," Sixth Edition (BPM6), Washington, D.C. https://www.imf.org/external/Pubs/FT/GFS/Manual/2014/gfsfinal.pdf.

IMF, 2015. "Balance of Payment and International Investment Position Statistics," Washington, D.C. https://www.imf.org/external/np/sta/bop/bop.htm.

IMF, 2016a. "IMF Crisis Lending Fact Sheet," Washington, D.C. http://www.imf.org/about/factsheets/sheets/2016/08/01/18/48/crisis-lending?pdf=1

IMF, 2016b. "Monitoring of Fund Arrangements (MONA) Dataset," Washington, D.C. https://www.imf.org/external/np/pdr/mona/index.aspx. 
Joutz, Frederick L. and Herman O. Stekler, 1998. "Data Revisions and Forecasting," Applied Economics, 30 (8), 1011-1016.

Lahiri, Kajal and Xuguang Sheng, 2010. "Learning and Heterogeneity in GDP and Inflation Forecasts," International Journal of Forecasting, 26 (2), 265-292.

Luna, Francesco, 2014. "IMF Forecasts in the Context of Program Countries," IEO/IMF Background Paper BP/14/05.

McNees, Stephen K., 1986. "Estimating GNP: The Trade-off between Timeliness and Accuracy," New England Economic Review, January/February, 3-10.

Merton, Robert C., 1981. "On Market Timing and Investment Performance. I. An Equilibrium Theory of Value for Market Forecasts," Journal of Business, 54 (3), 363-406.

Mincer, Jacob A. and Victor Zarnowitz, 1969. "The Evaluation of Economic Forecasts," in Mincer, Jacob A., (Ed.), Economic Forecasts and Expectations, NBER, New York.

Musso, Alberto, and Steven Phillips, 2002. "Comparing Projections and Outcomes of IMFsupported Programs," IMF Staff Papers, 49 (1), 22-48.

Palm, Franz C. and Arnold Zellner, 1992. "To Combine or not to Combine? Issues of Combining Forecasts," Journal of Forecasting, 11 (8), 687-701.

Rosenthal, Jack, 2009. “A Terrible Thing to Waste,” July 31, 2009, New York Times Magazine.

Schnader, Marjorie H., and Herman O. Stekler, 1990. "Evaluating Predictions of Change," The Journal of Business, Vol. 63, No. 1, part 1, 99-107.

Sinclair, Tara M., Fred Joutz, and Herman O. Stekler, 2008. "Are 'Unbiased' Forecasts Really Unbiased? Another Look at the Fed Forecasts," RPF Working Paper 2008-010.

Sinclair, Tara M., Fred Joutz, and Herman O. Stekler, 2010. "Can the Fed Predict the State of the Economy?," Economics Letters, 108 (1), 28-32.

Sinclair, Tara M., and Herman O. Stekler, 2013. "Examining the Quality of Early GDP Component Estimates," International Journal of Forecasting, 29 (4), 736-750.

Silver, Nate, 2012. “The Signal and the Noise," The Penguin Press: New York.

Swanson, Norman R., and Dick van Dijk, 2006. "Are Statistical Reporting Agencies Getting It Right? Data Rationality and Business Cycle Asymmetry," Journal of Business and Economic Statistics, 24 (1), 24-42. 
Table 1: Mincer-Zarnowitz Regressions - GDP Growth

\begin{tabular}{|c|c|c|c|c|c|c|c|c|c|}
\hline \multicolumn{10}{|c|}{ Full Sample } \\
\hline $\begin{array}{l}\text { Dependent variable: } \\
\text { Actual growth rate }\end{array}$ & $\begin{array}{l}\text { Real } \\
\text { GDP }\end{array}$ & $\begin{array}{l}\text { Avg. } \\
\text { prices }\end{array}$ & GDP & $\begin{array}{l}\text { Private } \\
\text { Cons. }\end{array}$ & $\begin{array}{l}\text { Public } \\
\text { Cons. }\end{array}$ & Imports & Exports & $\begin{array}{l}\text { Public } \\
\text { Inv. }\end{array}$ & $\begin{array}{l}\text { Private } \\
\text { Inv. }\end{array}$ \\
\hline Forecast growth rate, $\beta$ & $\begin{array}{c}0.606 \\
(0.127)\end{array}$ & $\begin{array}{c}1.031 \\
(0.097)\end{array}$ & $\begin{array}{c}0.883 \\
(0.058)\end{array}$ & $\begin{array}{c}0.801 \\
(0.156)\end{array}$ & $\begin{array}{c}0.716 \\
(0.107)\end{array}$ & $\begin{array}{c}0.626 \\
(0.166)\end{array}$ & $\begin{array}{c}0.723 \\
(0.061)\end{array}$ & $\begin{array}{c}0.534 \\
(0.096)\end{array}$ & $\begin{array}{c}0.398 \\
(0.160)\end{array}$ \\
\hline Constant, $\alpha$ & $\begin{array}{c}0.006 \\
(0.008)\end{array}$ & $\begin{array}{l}-0.005 \\
(0.005)\end{array}$ & $\begin{array}{l}-0.009 \\
(0.010)\end{array}$ & $\begin{array}{c}0.002 \\
(0.019)\end{array}$ & $\begin{array}{c}0.036 \\
(0.014)\end{array}$ & $\begin{array}{c}0.018 \\
(0.027)\end{array}$ & $\begin{array}{c}0.027 \\
(0.020)\end{array}$ & $\begin{array}{l}-0.023 \\
(0.039)\end{array}$ & $\begin{array}{l}-0.007 \\
(0.035)\end{array}$ \\
\hline Crisis08 & $\begin{array}{l}-0.020 \\
(0.013)\end{array}$ & $\begin{array}{c}0.012 \\
(0.034)\end{array}$ & $\begin{array}{c}0.049 \\
(0.017)\end{array}$ & $\begin{array}{c}0.105 \\
(0.045)\end{array}$ & $\begin{array}{l}-0.004 \\
(0.043)\end{array}$ & $\begin{array}{c}0.197 \\
(0.069)\end{array}$ & $\begin{array}{c}0.028 \\
(0.034)\end{array}$ & $\begin{array}{c}0.052 \\
(0.076)\end{array}$ & $\begin{array}{c}0.175 \\
(0.069)\end{array}$ \\
\hline Africa & $\begin{array}{c}0.018 \\
(0.007)\end{array}$ & $\begin{array}{c}0.006 \\
(0.005)\end{array}$ & $\begin{array}{c}0.030 \\
(0.011)\end{array}$ & $\begin{array}{c}0.018 \\
(0.016)\end{array}$ & $\begin{array}{c}0.005 \\
(0.018)\end{array}$ & $\begin{array}{c}0.023 \\
(0.029)\end{array}$ & $\begin{array}{c}0.025 \\
(0.026)\end{array}$ & $\begin{array}{c}0.019 \\
(0.045)\end{array}$ & $\begin{array}{c}0.122 \\
(0.041)\end{array}$ \\
\hline America & $\begin{array}{c}0.008 \\
(0.011)\end{array}$ & $\begin{array}{c}0.003 \\
(0.007)\end{array}$ & $\begin{array}{c}0.028 \\
(0.012)\end{array}$ & $\begin{array}{c}0.015 \\
(0.017)\end{array}$ & $\begin{array}{l}-0.034 \\
(0.021)\end{array}$ & $\begin{array}{c}0.074 \\
(0.040)\end{array}$ & $\begin{array}{c}0.109 \\
(0.039)\end{array}$ & $\begin{array}{c}0.036 \\
(0.055)\end{array}$ & $\begin{array}{c}0.087 \\
(0.064)\end{array}$ \\
\hline Asia & $\begin{array}{c}0.004 \\
(0.010)\end{array}$ & $\begin{array}{l}-0.017 \\
(0.011)\end{array}$ & $\begin{array}{c}0.017 \\
(0.013)\end{array}$ & $\begin{array}{l}-0.036 \\
(0.025)\end{array}$ & $\begin{array}{c}0.025 \\
(0.032)\end{array}$ & $\begin{array}{l}-0.014 \\
(0.039)\end{array}$ & $\begin{array}{c}0.017 \\
(0.028)\end{array}$ & $\begin{array}{c}0.109 \\
(0.047)\end{array}$ & $\begin{array}{c}0.056 \\
(0.048)\end{array}$ \\
\hline $\begin{array}{l}\text { Observations } \\
\text { R-squared }\end{array}$ & $\begin{array}{c}110 \\
0.463\end{array}$ & $\begin{array}{c}106 \\
0.748\end{array}$ & $\begin{array}{c}110 \\
0.785\end{array}$ & $\begin{array}{c}110 \\
0.682\end{array}$ & $\begin{array}{l}110 \\
0.448\end{array}$ & $\begin{array}{l}110 \\
0.490\end{array}$ & $\begin{array}{c}110 \\
0.574\end{array}$ & $\begin{array}{c}110 \\
0.345\end{array}$ & $\begin{array}{l}110 \\
0.207\end{array}$ \\
\hline $\begin{array}{l}\text { F-test }(\alpha=0, \beta=1) \\
\text { Holden-Peel t-test }\end{array}$ & $\begin{array}{c}5.495^{* * *} \\
-0.847\end{array}$ & $\begin{array}{c}0.948 \\
-1.130\end{array}$ & $\begin{array}{l}3.780^{* *} \\
-2.106 * *\end{array}$ & $\begin{array}{c}1.590 \\
-1.070\end{array}$ & $\begin{array}{c}5.058^{* * *} \\
1.544\end{array}$ & $\begin{array}{l}2.544^{*} \\
-0.136\end{array}$ & $\begin{array}{l}10.170 * * * \\
0.006\end{array}$ & $\begin{array}{l}16.150 * * * \\
-2.102 * *\end{array}$ & $\begin{array}{l}9.026^{* * *} \\
-2.338^{* *}\end{array}$ \\
\hline \multicolumn{10}{|c|}{ LIC Sample } \\
\hline $\begin{array}{l}\text { Dependent variable: } \\
\text { Actual growth rate }\end{array}$ & $\begin{array}{l}\text { Real } \\
\text { GDP }\end{array}$ & $\begin{array}{c}\text { Avg. } \\
\text { prices }\end{array}$ & GDP & $\begin{array}{l}\text { Private } \\
\text { Cons. }\end{array}$ & $\begin{array}{l}\text { Public } \\
\text { Cons. }\end{array}$ & Imports & Exports & $\begin{array}{l}\text { Public } \\
\text { Inv. }\end{array}$ & $\begin{array}{l}\text { Private } \\
\text { Inv. }\end{array}$ \\
\hline Forecast growth rate, $\beta$ & $\begin{array}{c}0.482 \\
(0.141)\end{array}$ & $\begin{array}{c}1.117 \\
(0.105)\end{array}$ & $\begin{array}{c}0.914 \\
(0.065)\end{array}$ & $\begin{array}{c}0.523 \\
(0.112)\end{array}$ & $\begin{array}{c}0.589 \\
(0.139)\end{array}$ & $\begin{array}{c}0.450 \\
(0.139)\end{array}$ & $\begin{array}{c}0.654 \\
(0.086)\end{array}$ & $\begin{array}{c}0.480 \\
(0.117)\end{array}$ & $\begin{array}{c}0.194 \\
(0.192)\end{array}$ \\
\hline Constant, $\alpha$ & $\begin{array}{c}0.017 \\
(0.013)\end{array}$ & $\begin{array}{l}-0.003 \\
(0.003)\end{array}$ & $\begin{array}{c}0.000 \\
(0.018)\end{array}$ & $\begin{array}{c}0.082 \\
(0.023)\end{array}$ & $\begin{array}{c}0.045 \\
(0.035)\end{array}$ & $\begin{array}{c}0.137 \\
(0.035)\end{array}$ & $\begin{array}{c}0.089 \\
(0.035)\end{array}$ & $\begin{array}{c}0.092 \\
(0.125)\end{array}$ & $\begin{array}{l}-0.012 \\
(0.044)\end{array}$ \\
\hline Crisis08 & $\begin{array}{l}-0.012 \\
(0.014)\end{array}$ & $\begin{array}{c}0.008 \\
(0.039)\end{array}$ & $\begin{array}{c}0.068 \\
(0.016)\end{array}$ & $\begin{array}{c}0.081 \\
(0.043)\end{array}$ & $\begin{array}{c}0.022 \\
(0.053)\end{array}$ & $\begin{array}{c}0.162 \\
(0.073)\end{array}$ & $\begin{array}{l}-0.013 \\
(0.032)\end{array}$ & $\begin{array}{c}0.128 \\
(0.049)\end{array}$ & $\begin{array}{c}0.149 \\
(0.088)\end{array}$ \\
\hline Africa & $\begin{array}{c}0.014 \\
(0.011)\end{array}$ & $\begin{array}{c}0.000 \\
(0.005)\end{array}$ & $\begin{array}{c}0.018 \\
(0.018)\end{array}$ & $\begin{array}{l}-0.030 \\
(0.024)\end{array}$ & $\begin{array}{c}0.010 \\
(0.037)\end{array}$ & $\begin{array}{l}-0.071 \\
(0.037)\end{array}$ & $\begin{array}{l}-0.017 \\
(0.038)\end{array}$ & $\begin{array}{l}-0.083 \\
(0.129)\end{array}$ & $\begin{array}{c}0.152 \\
(0.049)\end{array}$ \\
\hline America & $\begin{array}{c}0.000 \\
(0.015)\end{array}$ & $\begin{array}{l}-0.001 \\
(0.007)\end{array}$ & $\begin{array}{c}0.018 \\
(0.019)\end{array}$ & $\begin{array}{l}-0.016 \\
(0.033)\end{array}$ & $\begin{array}{l}-0.049 \\
(0.042)\end{array}$ & $\begin{array}{c}0.004 \\
(0.090)\end{array}$ & $\begin{array}{c}0.047 \\
(0.096)\end{array}$ & $\begin{array}{l}-0.054 \\
(0.143)\end{array}$ & $\begin{array}{c}0.021 \\
(0.105)\end{array}$ \\
\hline Asia & $\begin{array}{c}0.016 \\
(0.011)\end{array}$ & $\begin{array}{l}-0.025 \\
(0.016)\end{array}$ & $\begin{array}{c}0.006 \\
(0.020)\end{array}$ & $\begin{array}{l}-0.033 \\
(0.026)\end{array}$ & $\begin{array}{c}0.050 \\
(0.046)\end{array}$ & $\begin{array}{l}-0.048 \\
(0.037)\end{array}$ & $\begin{array}{l}-0.046 \\
(0.041)\end{array}$ & $\begin{array}{c}0.014 \\
(0.128)\end{array}$ & $\begin{array}{c}0.104 \\
(0.052)\end{array}$ \\
\hline "Observations & 74 & 73 & 74 & 74 & 74 & 74 & 74 & 74 & 74 \\
\hline R-squared & 0.504 & 0.653 & 0.782 & 0.359 & 0.325 & 0.293 & 0.516 & 0.332 & 0.123 \\
\hline F-test $(\alpha=0, \beta=1)$ & $7.600 * * *$ & 0.633 & 0.954 & $11.060 * * *$ & $4.550 * * *$ & $11.550 * * *$ & $8.920 * * *$ & $9.831 * * *$ & $11.540 * * *$ \\
\hline Holden-Peel t-test & -0.996 & -0.080 & -0.417 & $2.179 * *$ & 0.746 & $2.308 * *$ & 1.228 & 0.305 & $-2.297 * *$ \\
\hline \multicolumn{10}{|c|}{ Non-LIC Sample } \\
\hline $\begin{array}{l}\text { Dependent variable: } \\
\text { Actual growth rate }\end{array}$ & $\begin{array}{l}\text { Real } \\
\text { GDP }\end{array}$ & $\begin{array}{c}\text { Avg. } \\
\text { prices }\end{array}$ & GDP & $\begin{array}{l}\text { Private } \\
\text { Cons. }\end{array}$ & $\begin{array}{l}\text { Public } \\
\text { Cons. }\end{array}$ & Imports & Exports & $\begin{array}{l}\text { Public } \\
\text { Inv. }\end{array}$ & $\begin{array}{l}\text { Private } \\
\text { Inv. }\end{array}$ \\
\hline Forecast growth rate, $\beta$ & $\begin{array}{c}1.069 \\
(0.179)\end{array}$ & $\begin{array}{c}0.798 \\
(0.130)\end{array}$ & $\begin{array}{c}0.951 \\
(0.136)\end{array}$ & $\begin{array}{c}0.895 \\
(0.222)\end{array}$ & $\begin{array}{c}0.799 \\
(0.074)\end{array}$ & $\begin{array}{c}1.013 \\
(0.176)\end{array}$ & $\begin{array}{c}1.050 \\
(0.116)\end{array}$ & $\begin{array}{c}0.665 \\
(0.169)\end{array}$ & $\begin{array}{c}1.040 \\
(0.202)\end{array}$ \\
\hline Constant, $\alpha$ & $\begin{array}{l}-0.005 \\
(0.007)\end{array}$ & $\begin{array}{c}0.004 \\
(0.008)\end{array}$ & $\begin{array}{l}-0.014 \\
(0.015)\end{array}$ & $\begin{array}{l}-0.017 \\
(0.021)\end{array}$ & $\begin{array}{c}0.034 \\
(0.016)\end{array}$ & $\begin{array}{l}-0.017 \\
(0.024)\end{array}$ & $\begin{array}{l}-0.014 \\
(0.023)\end{array}$ & $\begin{array}{l}-0.050 \\
(0.048)\end{array}$ & $\begin{array}{l}-0.049 \\
(0.032)\end{array}$ \\
\hline Crisis08 & $\begin{array}{l}-0.038 \\
(0.006)\end{array}$ & $\begin{array}{c}0.080 \\
(0.043)\end{array}$ & $\begin{array}{l}-0.014 \\
(0.043)\end{array}$ & $\begin{array}{c}0.144 \\
(0.188)\end{array}$ & $\begin{array}{l}-0.042 \\
(0.029)\end{array}$ & $\begin{array}{c}0.152 \\
(0.131)\end{array}$ & $\begin{array}{c}0.039 \\
(0.058)\end{array}$ & $\begin{array}{l}-0.128 \\
(0.194)\end{array}$ & $\begin{array}{c}0.037 \\
(0.077)\end{array}$ \\
\hline Africa & $\begin{array}{c}0.001 \\
(0.008)\end{array}$ & $\begin{array}{l}-0.008 \\
(0.013)\end{array}$ & $\begin{array}{l}-0.001 \\
(0.013)\end{array}$ & $\begin{array}{c}0.026 \\
(0.062)\end{array}$ & $\begin{array}{l}-0.043 \\
(0.025)\end{array}$ & $\begin{array}{c}0.013 \\
(0.046)\end{array}$ & $\begin{array}{l}-0.026 \\
(0.026)\end{array}$ & $\begin{array}{l}-0.019 \\
(0.156)\end{array}$ & $\begin{array}{c}0.128 \\
(0.044)\end{array}$ \\
\hline America & $\begin{array}{c}0.004 \\
(0.015)\end{array}$ & $\begin{array}{c}0.010 \\
(0.007)\end{array}$ & $\begin{array}{c}0.024 \\
(0.016)\end{array}$ & $\begin{array}{c}0.012 \\
(0.020)\end{array}$ & $\begin{array}{l}-0.032 \\
(0.025)\end{array}$ & $\begin{array}{c}0.051 \\
(0.036)\end{array}$ & $\begin{array}{c}0.119 \\
(0.035)\end{array}$ & $\begin{array}{c}0.028 \\
(0.069)\end{array}$ & $\begin{array}{c}0.057 \\
(0.065)\end{array}$ \\
\hline Asia & $\begin{array}{l}-0.018 \\
(0.015) \\
\end{array}$ & $\begin{array}{c}-0.014 \\
(0.006) \\
\end{array}$ & $\begin{array}{c}0.009 \\
(0.017) \\
\end{array}$ & $\begin{array}{l}-0.066 \\
(0.034)\end{array}$ & $\begin{array}{c}0.004 \\
(0.055) \\
\end{array}$ & $\begin{array}{l}-0.056 \\
(0.052)\end{array}$ & $\begin{array}{c}0.044 \\
(0.029) \\
\end{array}$ & $\begin{array}{c}0.109 \\
(0.072) \\
\end{array}$ & $\begin{array}{c}0.004 \\
(0.072) \\
\end{array}$ \\
\hline "Observations & 36 & 33 & 36 & 36 & 36 & 36 & 36 & 36 & 36 \\
\hline R-squared & 0.396 & 0.934 & 0.832 & 0.865 & 0.721 & 0.839 & 0.819 & 0.440 & 0.557 \\
\hline F-test $(\alpha=0, \beta=1)$ & 0.223 & 2.202 & 1.593 & 1.876 & $4.141 * *$ & 0.271 & 0.231 & $4.882^{* *}$ & 1.385 \\
\hline Holden-Peel t-test & -0.482 & -1.607 & $-1.821 *$ & $-1.783 *$ & 1.446 & -0.733 & -0.479 & $-2.040 * *$ & -1.682 \\
\hline
\end{tabular}

Notes: Robust standard errors in parentheses. No significance values reported for individual coefficient estimates. $* * *, * *$ and $*$ indicate rejection of the null hypothesis of the Mincer-Zarnowitz F-test and the Holden-Peel t-test at the 10, 5 and 1 percent level of statistical significance, respectively. 
Table 2: Correct and Incorrect Forecasts of GDP and Its Subcomponent Growth Rates

\begin{tabular}{|l|c|c|c|c|c|}
\hline \multicolumn{1}{|c|}{ Full Sample } \\
\cline { 2 - 5 } \\
\cline { 2 - 6 } & $\begin{array}{c}\text { Forecast }>\mathbf{0} \\
\text { Actual }>\mathbf{0}\end{array}$ & $\begin{array}{c}\text { Forecast } \leq \mathbf{0} \\
\text { Actual } \leq \mathbf{0}\end{array}$ & $\begin{array}{c}\text { Forecast }>\mathbf{0} \\
\text { Actual } \leq \mathbf{0}\end{array}$ & $\begin{array}{c}\text { Forecast } \leq \mathbf{0} \\
\text { Actual }>\mathbf{0}\end{array}$ & $\begin{array}{c}\text { Chi Square } \\
\text { Value }\end{array}$ \\
\hline Real GDP Growth & 89.1 & 4.5 & 4.5 & 1.8 & $27.557 * * *$ \\
Inflation (avg. prices) & 89.6 & 0.0 & 8.5 & 1.9 & 0.189 \\
GDP Growth & 94.5 & 3.6 & 0.9 & 0.9 & $51.722^{* * *}$ \\
Private Consumption Growth & 90.0 & 3.6 & 5.5 & 0.9 & $23.514 * * *$ \\
Public Consumption Growth & 76.4 & 6.4 & 9.1 & 8.2 & $9.079^{* * *}$ \\
Import Growth & 81.8 & 7.3 & 8.2 & 2.7 & $26.006 * * *$ \\
Export Growth & 80.0 & 5.5 & 8.2 & 6.4 & $10.290^{* * *}$ \\
Public Investment Growth & 67.3 & 8.2 & 19.1 & 5.5 & $7.566^{* * *}$ \\
Private Investment Growth & 70.0 & 7.3 & 13.6 & 9.1 & $5.607 * *$ \\
\hline
\end{tabular}

\begin{tabular}{|c|c|c|c|c|c|}
\hline \multicolumn{6}{|c|}{ LIC Sample } \\
\hline & \multicolumn{2}{|c|}{ Correct (in \%) } & \multicolumn{2}{|c|}{ Incorrect (in \%) } & \multirow[b]{2}{*}{$\begin{array}{c}\text { Chi Square } \\
\text { Value }\end{array}$} \\
\hline & $\begin{array}{c}\text { Forecast }>0 \\
\text { Actual }>0\end{array}$ & $\begin{array}{c}\text { Forecast } \leq \mathbf{0} \\
\text { Actual } \leq \mathbf{0}\end{array}$ & $\begin{array}{c}\text { Forecast }>0 \\
\text { Actual } \leq 0\end{array}$ & $\begin{array}{c}\text { Forecast } \leq 0 \\
\text { Actual }>0\end{array}$ & \\
\hline Real GDP Growth & 93.2 & 2.7 & 1.4 & 2.7 & $12.161 * * *$ \\
\hline Inflation (avg. prices) & 89.0 & 0.0 & 8.2 & 2.7 & 0.184 \\
\hline GDP Growth & 95.9 & 2.7 & 0.0 & 1.4 & $26.599 * * *$ \\
\hline Private Consumption Growth & 93.2 & 1.4 & 4.1 & 1.4 & 1.544 \\
\hline Public Consumption Growth & 78.4 & 4.1 & 6.8 & 10.8 & 1.903 \\
\hline Import Growth & 83.8 & 5.4 & 8.1 & 2.7 & $11.223 * * *$ \\
\hline Export Growth & 82.4 & 2.7 & 8.1 & 6.8 & 0.904 \\
\hline Public Investment Growth & 70.3 & 6.8 & 14.9 & 8.1 & $2.836^{*}$ \\
\hline Private Investment Growth & 68.9 & 5.4 & 12.2 & 13.5 & 0.659 \\
\hline
\end{tabular}

\begin{tabular}{|l|c|c|c|c|c|}
\hline \multicolumn{1}{|c|}{ Non-LIC Sample } \\
\hline & \multicolumn{2}{|c|}{ Correct (in \%) } & \multicolumn{2}{c|}{ Incorrect (in \%) } \\
\cline { 2 - 5 } & $\begin{array}{c}\text { Forecast }>\mathbf{0} \\
\text { Actual }>\mathbf{0}\end{array}$ & $\begin{array}{c}\text { Forecast } \leq \mathbf{0} \\
\text { Actual } \leq \mathbf{0}\end{array}$ & $\begin{array}{c}\text { Forecast }>\mathbf{0} \\
\text { Actual } \leq \mathbf{0}\end{array}$ & $\begin{array}{c}\text { Forecast } \leq \mathbf{0} \\
\text { Actual }>\mathbf{0}\end{array}$ & $\begin{array}{c}\text { Chi Square } \\
\text { Value }\end{array}$ \\
\hline Real GDP Growth & 80.6 & 8.3 & 11.1 & 0.0 & $8.528^{* * *}$ \\
Inflation (avg. prices) & 90.9 & 0.0 & 9.1 & 0.0 & $\mathrm{~N} / \mathrm{A}$ \\
GDP Growth & 91.7 & 5.6 & 2.8 & 0.0 & $12.321^{* * *}$ \\
Private Consumption Growth & 83.3 & 8.3 & 8.3 & 0.0 & $10.473^{* * *}$ \\
Public Consumption Growth & 72.2 & 11.1 & 13.9 & 2.8 & $6.251^{* *}$ \\
Import Growth & 77.8 & 11.1 & 8.3 & 2.8 & $9.475^{* * *}$ \\
Export Growth & 75.0 & 11.1 & 8.3 & 5.6 & $6.952^{* * *}$ \\
Public Investment Growth & 61.1 & 11.1 & 27.8 & 0.0 & $4.474^{* *}$ \\
Private Investment Growth & 72.2 & 11.1 & 16.7 & 0.0 & $8.000^{* * *}$ \\
\hline
\end{tabular}

Notes: $* * * * *$ and $*$ indicate 1,5 and 10 percent level of statistical significance, respectively. 
Table 3: Contributors to GDP Growth Forecast Errors

\begin{tabular}{|c|c|c|c|}
\hline \multirow{2}{*}{$\begin{array}{l}\text { Dependent variable: GDP growth } \\
\text { (Forecast Error, FE) }\end{array}$} & $3 a$ & $3 \mathbf{b}$ & $3 c$ \\
\hline & All & LICs & Non-LICs \\
\hline \multirow{2}{*}{$\begin{array}{l}\text { Private Consumption Growth } \\
\text { (FE) }\end{array}$} & $0.429 * * *$ & $0.484 * * *$ & $0.286^{* *}$ \\
\hline & $(0.076)$ & $(0.071)$ & $(0.108)$ \\
\hline \multirow{2}{*}{$\begin{array}{l}\text { Public Consumption Growth } \\
\text { (FE) }\end{array}$} & $0.090 * *$ & $0.112 * *$ & 0.091 \\
\hline & $(0.041)$ & $(0.042)$ & $(0.068)$ \\
\hline \multirow{2}{*}{$\begin{array}{l}\text { Import Growth } \\
\text { (FE) }\end{array}$} & $-0.200 * * *$ & $-0.195 * * *$ & $-0.253 * *$ \\
\hline & $(0.066)$ & $(0.071)$ & $(0.108)$ \\
\hline \multirow{2}{*}{$\begin{array}{l}\text { Export Growth } \\
\text { (FE) }\end{array}$} & $0.171^{* * *}$ & $0.142 * *$ & $0.329 * * *$ \\
\hline & $(0.049)$ & $(0.056)$ & $(0.058)$ \\
\hline \multirow{2}{*}{$\begin{array}{l}\text { Public Investment Growth } \\
\text { (FE) }\end{array}$} & $0.047 * * *$ & $0.054 * * *$ & 0.031 \\
\hline & $(0.014)$ & $(0.014)$ & $(0.028)$ \\
\hline \multirow{2}{*}{$\begin{array}{l}\text { Private Investment Growth } \\
\text { (FE) }\end{array}$} & $0.092 * * *$ & $0.091 * * *$ & $0.123^{* * *}$ \\
\hline & $(0.016)$ & $(0.016)$ & $(0.040)$ \\
\hline \multirow[t]{2}{*}{ Constant } & $-0.006^{*}$ & $-0.010 * * *$ & $0.012 *$ \\
\hline & $(0.003)$ & $(0.004)$ & $(0.006)$ \\
\hline "Observations & 1110 & $\overline{774}$ & 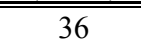 \\
\hline R-squared & 0.488 & 0.526 & 0.612 \\
\hline
\end{tabular}

Notes: All variables are forecast errors of growth rates. Robust standard errors in parenthesis. ${ }^{* *}, * *$ and $*$ indicate 1,5 and 10 percent level of statistical significance, respectively. 
Table 4a: Mincer-Zarnowitz Regressions - Current Account Balance Growth

\begin{tabular}{|c|c|c|c|c|c|c|c|}
\hline \multicolumn{8}{|c|}{ Full Sample } \\
\hline $\begin{array}{l}\text { Dependent variable: } \\
\text { Actual growth rate }\end{array}$ & $\begin{array}{l}\text { Current } \\
\text { Account }\end{array}$ & $\begin{array}{c}\text { Goods } \\
\text { Imports }\end{array}$ & $\begin{array}{c}\text { Goods } \\
\text { Exports }\end{array}$ & $\begin{array}{l}\text { Services } \\
\text { Imports }\end{array}$ & $\begin{array}{l}\text { Services } \\
\text { Exports }\end{array}$ & $\begin{array}{c}\text { Net } \\
\text { Transfers }\end{array}$ & $\begin{array}{c}\text { Net } \\
\text { Income }\end{array}$ \\
\hline Forecast growth rate, $\beta$ & $\begin{array}{c}0.164 \\
(0.061)\end{array}$ & $\begin{array}{c}0.705 \\
(0.123)\end{array}$ & $\begin{array}{c}0.827 \\
(0.084)\end{array}$ & $\begin{array}{c}0.576 \\
(0.105)\end{array}$ & $\begin{array}{c}0.276 \\
(0.192)\end{array}$ & $\begin{array}{c}0.083 \\
(0.107)\end{array}$ & $\begin{array}{c}0.247 \\
(0.098)\end{array}$ \\
\hline Constant, $\alpha$ & $\begin{array}{l}-0.096 \\
(0.121)\end{array}$ & $\begin{array}{c}0.010 \\
(0.028)\end{array}$ & $\begin{array}{c}0.035 \\
(0.029)\end{array}$ & $\begin{array}{c}0.052 \\
(0.029)\end{array}$ & $\begin{array}{c}0.038 \\
(0.034)\end{array}$ & $\begin{array}{c}0.162 \\
(0.082)\end{array}$ & $\begin{array}{c}0.055 \\
(0.081)\end{array}$ \\
\hline Crisis08 & $\begin{array}{c}0.288 \\
(0.309)\end{array}$ & $\begin{array}{c}0.114 \\
(0.056)\end{array}$ & $\begin{array}{l}-0.017 \\
(0.053)\end{array}$ & $\begin{array}{c}0.061 \\
(0.056)\end{array}$ & $\begin{array}{c}0.178 \\
(0.116)\end{array}$ & $\begin{array}{c}0.021 \\
(0.231)\end{array}$ & $\begin{array}{l}-0.083 \\
(0.216)\end{array}$ \\
\hline Africa & $\begin{array}{c}0.153 \\
(0.188)\end{array}$ & $\begin{array}{c}0.025 \\
(0.033)\end{array}$ & $\begin{array}{c}0.025 \\
(0.034)\end{array}$ & $\begin{array}{c}0.002 \\
(0.035)\end{array}$ & $\begin{array}{c}0.043 \\
(0.041)\end{array}$ & $\begin{array}{l}-0.055 \\
(0.095)\end{array}$ & $\begin{array}{l}-0.039 \\
(0.125)\end{array}$ \\
\hline America & $\begin{array}{l}-0.155 \\
(0.184)\end{array}$ & $\begin{array}{c}0.045 \\
(0.046)\end{array}$ & $\begin{array}{c}0.027 \\
(0.038)\end{array}$ & $\begin{array}{l}-0.021 \\
(0.040)\end{array}$ & $\begin{array}{c}0.021 \\
(0.040)\end{array}$ & $\begin{array}{c}0.084 \\
(0.112)\end{array}$ & $\begin{array}{l}-0.038 \\
(0.122)\end{array}$ \\
\hline Asia & $\begin{array}{l}-0.023 \\
(0.187)\end{array}$ & $\begin{array}{c}0.015 \\
(0.048)\end{array}$ & $\begin{array}{c}0.027 \\
(0.061)\end{array}$ & $\begin{array}{c}0.054 \\
(0.067)\end{array}$ & $\begin{array}{c}0.107 \\
(0.054)\end{array}$ & $\begin{array}{c}0.050 \\
(0.143)\end{array}$ & $\begin{array}{c}0.348 \\
(0.256)\end{array}$ \\
\hline $\begin{array}{l}\text { Observations } \\
\text { R-squared }\end{array}$ & $\begin{array}{c}132 \\
0.069\end{array}$ & $\begin{array}{c}132 \\
0.411\end{array}$ & $\begin{array}{c}132 \\
0.432\end{array}$ & $\begin{array}{c}132 \\
0.201\end{array}$ & $\begin{array}{c}132 \\
0.109\end{array}$ & $\begin{array}{c}132 \\
0.023\end{array}$ & $\begin{array}{c}132 \\
0.175\end{array}$ \\
\hline $\begin{array}{l}\text { F-test }(\alpha=0, \beta=1) \\
\text { Holden-Peel t-test }\end{array}$ & $\begin{array}{c}95.560 * * * \\
0.421 * * \\
\end{array}$ & $\begin{array}{c}2.870^{*} \\
0.433 \\
\end{array}$ & $\begin{array}{l}2.307 \\
0.931 \\
\end{array}$ & $\begin{array}{c}9.125 * * * \\
2.018 \\
\end{array}$ & $\begin{array}{c}7.223 * * * \\
0.241 \\
\end{array}$ & $\begin{array}{c}39.740^{* * *} \\
2.215^{* *} \\
\end{array}$ & $\begin{array}{c}29.520^{* * *} \\
-0.483 \\
\end{array}$ \\
\hline \multicolumn{8}{|c|}{ LIC Sample } \\
\hline $\begin{array}{l}\text { Dependent variable: } \\
\text { Actual growth rate }\end{array}$ & $\begin{array}{l}\text { Current } \\
\text { Account }\end{array}$ & $\begin{array}{c}\text { Goods } \\
\text { Imports }\end{array}$ & $\begin{array}{c}\text { Goods } \\
\text { Exports }\end{array}$ & $\begin{array}{l}\text { Services } \\
\text { Imports }\end{array}$ & $\begin{array}{l}\text { Services } \\
\text { Exports }\end{array}$ & $\begin{array}{c}\text { Net } \\
\text { Transfers }\end{array}$ & $\begin{array}{c}\text { Net } \\
\text { Income }\end{array}$ \\
\hline Forecast growth rate, $\beta$ & $\begin{array}{c}0.141 \\
(0.063)\end{array}$ & $\begin{array}{c}0.536 \\
(0.141)\end{array}$ & $\begin{array}{c}0.792 \\
(0.101)\end{array}$ & $\begin{array}{c}0.531 \\
(0.136)\end{array}$ & $\begin{array}{l}-0.039 \\
(0.314)\end{array}$ & $\begin{array}{c}0.043 \\
(0.144)\end{array}$ & $\begin{array}{c}0.258 \\
(0.101)\end{array}$ \\
\hline Constant, $\alpha$ & $\begin{array}{c}0.549 \\
(0.340)\end{array}$ & $\begin{array}{c}0.148 \\
(0.042)\end{array}$ & $\begin{array}{c}0.122 \\
(0.065)\end{array}$ & $\begin{array}{c}0.147 \\
(0.041)\end{array}$ & $\begin{array}{c}0.157 \\
(0.053)\end{array}$ & $\begin{array}{c}0.121 \\
(0.032)\end{array}$ & $\begin{array}{c}0.280 \\
(0.172)\end{array}$ \\
\hline Crisis08 & $\begin{array}{c}0.103 \\
(0.394)\end{array}$ & $\begin{array}{c}0.144 \\
(0.066)\end{array}$ & $\begin{array}{l}-0.028 \\
(0.074)\end{array}$ & $\begin{array}{c}0.047 \\
(0.079)\end{array}$ & $\begin{array}{c}0.265 \\
(0.167)\end{array}$ & $\begin{array}{l}-0.225 \\
(0.255)\end{array}$ & $\begin{array}{l}-0.317 \\
(0.213)\end{array}$ \\
\hline Africa & $\begin{array}{l}-0.498 \\
(0.382)\end{array}$ & $\begin{array}{l}-0.093 \\
(0.045)\end{array}$ & $\begin{array}{l}-0.049 \\
(0.069)\end{array}$ & $\begin{array}{l}-0.090 \\
(0.046)\end{array}$ & $\begin{array}{l}-0.062 \\
(0.054)\end{array}$ & $\begin{array}{c}0.002 \\
(0.058)\end{array}$ & $\begin{array}{l}-0.239 \\
(0.200)\end{array}$ \\
\hline America & $\begin{array}{l}-0.551 \\
(0.348)\end{array}$ & $\begin{array}{l}-0.075 \\
(0.072)\end{array}$ & $\begin{array}{l}-0.137 \\
(0.075)\end{array}$ & $\begin{array}{l}-0.116 \\
(0.053)\end{array}$ & $\begin{array}{l}-0.096 \\
(0.056)\end{array}$ & $\begin{array}{c}0.084 \\
(0.118)\end{array}$ & $\begin{array}{l}-0.100 \\
(0.236)\end{array}$ \\
\hline Asia & $\begin{array}{l}-0.587 \\
(0.381)\end{array}$ & $\begin{array}{l}-0.071 \\
(0.065)\end{array}$ & $\begin{array}{l}-0.036 \\
(0.095)\end{array}$ & $\begin{array}{c}0.005 \\
(0.086)\end{array}$ & $\begin{array}{c}0.025 \\
(0.074)\end{array}$ & $\begin{array}{c}0.002 \\
(0.078)\end{array}$ & $\begin{array}{c}0.283 \\
(0.365)\end{array}$ \\
\hline "Observations & 86 & 86 & 86 & 86 & 86 & 86 & 86 \\
\hline R-squared & 0.044 & 0.321 & 0.418 & 0.177 & 0.105 & 0.034 & 0.227 \\
\hline F-test $(\alpha=0, \beta=1)$ & $95.120 * * *$ & $8.971 * * *$ & $3.332 * *$ & $9.814^{* * *}$ & $6.596 * * *$ & $24.980 * * *$ & $27.390 * * *$ \\
\hline Holden-Peel t-test & 1.238 & $2.793 * * *$ & 1.474 & $2.763 * * *$ & 1.165 & 1.215 & 0.538 \\
\hline \multicolumn{8}{|c|}{ Non-LIC Sample } \\
\hline $\begin{array}{l}\text { Dependent variable: } \\
\text { Actual growth rate }\end{array}$ & $\begin{array}{l}\text { Current } \\
\text { Account }\end{array}$ & $\begin{array}{c}\text { Goods } \\
\text { Imports }\end{array}$ & $\begin{array}{c}\text { Goods } \\
\text { Exports }\end{array}$ & $\begin{array}{l}\text { Services } \\
\text { Imports }\end{array}$ & $\begin{array}{l}\text { Services } \\
\text { Exports }\end{array}$ & $\begin{array}{c}\text { Net } \\
\text { Transfers }\end{array}$ & $\begin{array}{c}\text { Net } \\
\text { Income }\end{array}$ \\
\hline Forecast growth rate, $\beta$ & $\begin{array}{c}0.251 \\
(0.218)\end{array}$ & $\begin{array}{c}0.964 \\
(0.116)\end{array}$ & $\begin{array}{c}0.885 \\
(0.164)\end{array}$ & $\begin{array}{c}0.666 \\
(0.198)\end{array}$ & $\begin{array}{c}0.647 \\
(0.220)\end{array}$ & $\begin{array}{c}0.140 \\
(0.204)\end{array}$ & $\begin{array}{c}0.135 \\
(0.195)\end{array}$ \\
\hline Constant, $\alpha$ & $\begin{array}{l}-0.232 \\
(0.114)\end{array}$ & $\begin{array}{l}-0.010 \\
(0.028)\end{array}$ & $\begin{array}{c}0.011 \\
(0.034)\end{array}$ & $\begin{array}{c}0.034 \\
(0.033)\end{array}$ & $\begin{array}{c}0.016 \\
(0.037)\end{array}$ & $\begin{array}{c}0.128 \\
(0.100)\end{array}$ & $\begin{array}{l}-0.025 \\
(0.084)\end{array}$ \\
\hline Crisis08 & $\begin{array}{c}0.630 \\
(0.395)\end{array}$ & $\begin{array}{c}0.084 \\
(0.079)\end{array}$ & $\begin{array}{c}0.035 \\
(0.058)\end{array}$ & $\begin{array}{c}0.085 \\
(0.058)\end{array}$ & $\begin{array}{c}0.043 \\
(0.062)\end{array}$ & $\begin{array}{c}0.452 \\
(0.410)\end{array}$ & $\begin{array}{c}0.484 \\
(0.447)\end{array}$ \\
\hline Africa & $\begin{array}{c}0.604 \\
(0.243)\end{array}$ & $\begin{array}{l}-0.005 \\
(0.066)\end{array}$ & $\begin{array}{c}-0.067 \\
(0.094)\end{array}$ & $\begin{array}{c}0.049 \\
(0.091)\end{array}$ & $\begin{array}{c}0.085 \\
(0.092)\end{array}$ & $\begin{array}{c}0.095 \\
(0.299)\end{array}$ & $\begin{array}{l}-0.150 \\
(0.241)\end{array}$ \\
\hline America & $\begin{array}{l}-0.146 \\
(0.214)\end{array}$ & $\begin{array}{c}0.047 \\
(0.055)\end{array}$ & $\begin{array}{c}0.084 \\
(0.043)\end{array}$ & $\begin{array}{c}-0.005 \\
(0.050)\end{array}$ & $\begin{array}{c}0.023 \\
(0.048)\end{array}$ & $\begin{array}{c}0.138 \\
(0.145)\end{array}$ & $\begin{array}{l}-0.032 \\
(0.137)\end{array}$ \\
\hline Asia & $\begin{array}{l}-0.126 \\
(0.278) \\
\end{array}$ & $\begin{array}{l}-0.059 \\
(0.061) \\
\end{array}$ & $\begin{array}{l}-0.021 \\
(0.053) \\
\end{array}$ & $\begin{array}{l}-0.061 \\
(0.051) \\
\end{array}$ & $\begin{array}{r}0.073 \\
(0.096) \\
\end{array}$ & $\begin{array}{r}0.364 \\
(0.416) \\
\end{array}$ & $\begin{array}{l}-0.031 \\
(0.152) \\
\end{array}$ \\
\hline Observations & 46 & 46 & 46 & 46 & 46 & 46 & 46 \\
\hline R-squared & 0.276 & 0.560 & 0.536 & 0.292 & 0.250 & 0.113 & 0.116 \\
\hline F-test $(\alpha=0, \beta=1)$ & $5.954 * * *$ & 0.124 & 0.253 & 1.737 & 1.467 & $10.100 * * *$ & $12.300 * * *$ \\
\hline Holden-Peel t-test & -0.375 & -0.328 & 0.220 & 1.312 & 0.131 & $1.928^{*}$ & -1.140 \\
\hline
\end{tabular}


Table 4b: Mincer-Zarnowitz Regressions - Financial Account Balance Growth

\begin{tabular}{|c|c|c|c|c|c|}
\hline \multicolumn{6}{|c|}{ Full Sample } \\
\hline $\begin{array}{l}\text { Dependent variable: } \\
\text { Actual growth rate }\end{array}$ & $\begin{array}{c}\text { Financial } \\
\text { Account }\end{array}$ & $\begin{array}{l}\text { Net Direct } \\
\text { Inv. }\end{array}$ & $\begin{array}{l}\text { Reserve } \\
\text { Assets }\end{array}$ & $\begin{array}{l}\text { Other } \\
\text { Inv. }\end{array}$ & $\begin{array}{l}\text { Net Portfolio } \\
\text { Inv. }\end{array}$ \\
\hline Forecast growth rate, $\beta$ & $\begin{array}{c}1.025 \\
(0.363)\end{array}$ & $\begin{array}{c}0.595 \\
(0.020)\end{array}$ & $\begin{array}{c}0.741 \\
(0.475)\end{array}$ & $\begin{array}{c}1.167 \\
(0.053)\end{array}$ & $\begin{array}{l}-0.144 \\
(0.238)\end{array}$ \\
\hline Constant, $\alpha$ & $\begin{array}{c}0.265 \\
(0.282)\end{array}$ & $\begin{array}{c}0.061 \\
(0.249)\end{array}$ & $\begin{array}{c}0.933 \\
(2.235)\end{array}$ & $\begin{array}{c}3.407 \\
(5.746)\end{array}$ & $\begin{array}{l}-1.016 \\
(0.492)\end{array}$ \\
\hline Crisis08 & $\begin{array}{c}2.306 \\
(1.084)\end{array}$ & $\begin{array}{c}0.536 \\
(0.556)\end{array}$ & $\begin{array}{l}-2.307 \\
(2.074)\end{array}$ & $\begin{array}{l}-10.103 \\
(7.493)\end{array}$ & $\begin{array}{l}-0.350 \\
(0.677)\end{array}$ \\
\hline Africa & $\begin{array}{l}-0.279 \\
(0.516)\end{array}$ & $\begin{array}{c}0.060 \\
(0.271)\end{array}$ & $\begin{array}{l}-0.681 \\
(2.283)\end{array}$ & $\begin{array}{l}-0.399 \\
(6.151)\end{array}$ & $\begin{array}{c}0.883 \\
(0.840)\end{array}$ \\
\hline America & $\begin{array}{l}-0.277 \\
(0.714)\end{array}$ & $\begin{array}{l}-0.237 \\
(0.313)\end{array}$ & $\begin{array}{l}-2.559 \\
(2.450)\end{array}$ & $\begin{array}{l}-1.320 \\
(6.613)\end{array}$ & $\begin{array}{l}1.212 \\
(0.656)\end{array}$ \\
\hline Asia & $\begin{array}{r}0.039 \\
(0.340) \\
\end{array}$ & $\begin{array}{l}-0.168 \\
(0.326) \\
\end{array}$ & $\begin{array}{l}-1.583 \\
(2.258) \\
\end{array}$ & $\begin{array}{l}-6.895 \\
(5.936) \\
\end{array}$ & $\begin{array}{l}-0.370 \\
(2.037) \\
\end{array}$ \\
\hline $\begin{array}{l}\text { Observations } \\
\text { R-squared }\end{array}$ & $\begin{array}{c}61 \\
0.599\end{array}$ & $\begin{array}{c}61 \\
0.782\end{array}$ & $\begin{array}{c}61 \\
0.198\end{array}$ & $\begin{array}{c}61 \\
0.743\end{array}$ & $\begin{array}{c}61 \\
0.046\end{array}$ \\
\hline F-test $(\alpha=0, \beta=1)$ & 0.469 & $243.500 * * *$ & 0.244 & $5.211 * * *$ & $11.620 * * *$ \\
\hline Holden-Peel t-test & 0.891 & -0.234 & 0.666 & 0.621 & -0.303 \\
\hline \multicolumn{6}{|c|}{ LIC Sample } \\
\hline $\begin{array}{l}\text { Dependent variable: } \\
\text { Actual growth rate }\end{array}$ & $\begin{array}{c}\text { Financial } \\
\text { Account }\end{array}$ & $\begin{array}{l}\text { Net Direct } \\
\text { Inv. }\end{array}$ & $\begin{array}{c}\text { Reserve } \\
\text { Assets }\end{array}$ & $\begin{array}{l}\text { Other } \\
\text { Inv. }\end{array}$ & $\begin{array}{c}\text { Net Portfolio } \\
\text { Inv. }\end{array}$ \\
\hline Forecast growth rate, $\beta$ & $\begin{array}{c}1.211 \\
(0.280)\end{array}$ & $\begin{array}{c}0.587 \\
(0.014)\end{array}$ & $\begin{array}{c}0.310 \\
(0.063)\end{array}$ & $\begin{array}{c}1.199 \\
(0.014)\end{array}$ & $\begin{array}{c}0.294 \\
(0.150)\end{array}$ \\
\hline Constant, $\alpha$ & $\begin{array}{l}1.038 \\
(0.667)\end{array}$ & $\begin{array}{l}-0.236 \\
(0.032)\end{array}$ & $\begin{array}{l}-1.355 \\
(0.372)\end{array}$ & $\begin{array}{c}1.197 \\
(0.623)\end{array}$ & $\begin{array}{l}-2.852 \\
(0.741)\end{array}$ \\
\hline Crisis08 & $\begin{array}{c}2.512 \\
(1.688)\end{array}$ & $\begin{array}{c}0.870 \\
(0.910)\end{array}$ & $\begin{array}{l}-0.758 \\
(1.072)\end{array}$ & $\begin{array}{l}-1.721 \\
(1.949)\end{array}$ & $\begin{array}{l}-0.755 \\
(0.992)\end{array}$ \\
\hline Africa & $\begin{array}{l}-1.106 \\
(0.763)\end{array}$ & $\begin{array}{c}0.349 \\
(0.120)\end{array}$ & $\begin{array}{c}1.509 \\
(1.022)\end{array}$ & $\begin{array}{c}0.959 \\
(2.007)\end{array}$ & $\begin{array}{c}3.300 \\
(1.179)\end{array}$ \\
\hline America & $\begin{array}{l}-1.260 \\
(0.747)\end{array}$ & $\begin{array}{c}0.249 \\
(0.195)\end{array}$ & $\begin{array}{c}0.276 \\
(2.743)\end{array}$ & $\begin{array}{l}-1.274 \\
(0.959)\end{array}$ & $\begin{array}{c}2.338 \\
(0.822)\end{array}$ \\
\hline Asia & $\begin{array}{l}-0.338 \\
(0.713) \\
\end{array}$ & $\begin{array}{l}-0.050 \\
(0.392) \\
\end{array}$ & $\begin{array}{c}0.624 \\
(0.478) \\
\end{array}$ & $\begin{array}{l}-4.534 \\
(1.770) \\
\end{array}$ & $\begin{array}{r}0.852 \\
(3.316) \\
\end{array}$ \\
\hline Observations & 34 & 34 & 34 & 34 & 34 \\
\hline R-squared & 0.809 & 0.873 & 0.092 & 0.943 & 0.101 \\
\hline F-test $(\alpha=0, \beta=1)$ & 1.233 & $571.700 * * *$ & $59.810 * * *$ & $99.770 * * *$ & $18.620 * * *$ \\
\hline Holden-Peel t-test & 1.678 & $-2.099 * *$ & $-3.153 * * *$ & 1.595 & $-3.750 * * *$ \\
\hline \multicolumn{6}{|c|}{ Non-LIC Sample } \\
\hline $\begin{array}{l}\text { Dependent variable: } \\
\text { Actual growth rate }\end{array}$ & $\begin{array}{c}\text { Financial } \\
\text { Account }\end{array}$ & $\begin{array}{c}\text { Net Direct } \\
\text { Inv. }\end{array}$ & $\begin{array}{c}\text { Reserve } \\
\text { Assets }\end{array}$ & $\begin{array}{l}\text { Other } \\
\text { Inv. }\end{array}$ & $\begin{array}{l}\text { Net Portfolio } \\
\text { Inv. }\end{array}$ \\
\hline Forecast growth rate, $\beta$ & $\begin{array}{l}-0.268 \\
(0.259)\end{array}$ & $\begin{array}{c}0.980 \\
(0.548)\end{array}$ & $\begin{array}{l}1.265 \\
(0.828)\end{array}$ & $\begin{array}{l}-1.846 \\
(0.964)\end{array}$ & $\begin{array}{l}-0.426 \\
(0.098)\end{array}$ \\
\hline Constant, $\alpha$ & $\begin{array}{c}0.027 \\
(0.468)\end{array}$ & $\begin{array}{c}0.091 \\
(0.225)\end{array}$ & $\begin{array}{c}2.331 \\
(2.876)\end{array}$ & $\begin{array}{c}6.320 \\
(6.791)\end{array}$ & $\begin{array}{c}-0.962 \\
(0.551)\end{array}$ \\
\hline Crisis08 & $\begin{array}{c}1.741 \\
(1.035)\end{array}$ & $\begin{array}{l}-0.017 \\
(0.284)\end{array}$ & $\begin{array}{l}-0.796 \\
(1.860)\end{array}$ & $\begin{array}{c}2.851 \\
(6.137)\end{array}$ & $\begin{array}{c}0.008 \\
(0.667)\end{array}$ \\
\hline Africa & $\begin{array}{l}-1.853 \\
(1.490)\end{array}$ & $\begin{array}{c}-0.084 \\
(0.282)\end{array}$ & $\begin{array}{l}-1.766 \\
(2.445)\end{array}$ & $\begin{array}{l}-8.488 \\
(8.562)\end{array}$ & $\begin{array}{l}-1.137 \\
(0.552)\end{array}$ \\
\hline America & $\begin{array}{l}-0.156 \\
(0.976)\end{array}$ & $\begin{array}{l}-0.296 \\
(0.426)\end{array}$ & $\begin{array}{c}-4.082 \\
(3.064)\end{array}$ & $\begin{array}{l}-5.653 \\
(8.530)\end{array}$ & $\begin{array}{c}0.568 \\
(0.801)\end{array}$ \\
\hline Asia & $\begin{array}{c}-0.544 \\
(0.579) \\
\end{array}$ & $\begin{array}{c}-0.034 \\
(0.233) \\
\end{array}$ & $\begin{array}{l}-3.253 \\
(2.926) \\
\end{array}$ & $\begin{array}{l}-4.916 \\
(6.723) \\
\end{array}$ & $\begin{array}{c}0.518 \\
(2.066) \\
\end{array}$ \\
\hline Observations & 27 & 27 & 27 & 27 & 27 \\
\hline R-squared & 0.121 & 0.393 & 0.337 & 0.169 & 0.464 \\
\hline F-test $(\alpha=0, \beta=1)$ & $13.680 * * *$ & 0.0897 & 0.337 & $9.766^{* * *}$ & $105.900 * * *$ \\
\hline Holden-Peel t-test & 0.927 & 0.337 & 0.545 & 0.744 & 0.471 \\
\hline
\end{tabular}

Notes: Robust standard errors in parentheses. No significance values reported for individual coefficient estimates. ***, ** and * indicate rejection of the null hypothesis of the Mincer-Zarnowitz F-test and the Holden-Peel t-test at the 10, 5 and 1 percent level of statistical significance, respectively. 
Table 5a: Correct and Incorrect Forecasts of Current Account and Its Subcomponent Growth Rates

\begin{tabular}{|c|c|c|c|c|c|}
\hline \multicolumn{6}{|c|}{ Full Sample } \\
\hline & \multicolumn{2}{|c|}{ Correct (in \%) } & \multicolumn{2}{|c|}{ Incorrect (in \%) } & \multirow[b]{2}{*}{$\begin{array}{c}\text { Chi Square } \\
\text { Value }\end{array}$} \\
\hline & $\begin{array}{c}\text { Forecast }>0 \\
\text { Actual }>0\end{array}$ & $\begin{array}{c}\text { Forecast } \leq \mathbf{0} \\
\text { Actual } \leq \mathbf{0}\end{array}$ & $\begin{array}{c}\text { Forecast }>0 \\
\text { Actual } \leq \mathbf{0}\end{array}$ & $\begin{array}{c}\text { Forecast } \leq \mathbf{0} \\
\text { Actual }>\mathbf{0}\end{array}$ & \\
\hline Current Account Growth & 34.1 & 34.1 & 19.7 & 12.1 & $16.754^{* * *}$ \\
\hline Goods Import Growth & 66.7 & 19.7 & 9.8 & 3.8 & $54.081 * * *$ \\
\hline Goods Export Growth & 73.5 & 12.1 & 7.6 & 6.8 & $34.893 * * *$ \\
\hline Services Import Growth & 64.4 & 14.4 & 12.9 & 8.3 & $23.154 * * *$ \\
\hline Services Export Growth & 69.7 & 12.1 & 11.4 & 6.8 & $25.460 * * *$ \\
\hline Net Transfers Growth & 47.7 & 14.4 & 13.6 & 24.2 & $2.800^{*}$ \\
\hline Net Income Growth & 34.1 & 23.5 & 21.2 & 21.2 & 2.114 \\
\hline
\end{tabular}

\begin{tabular}{|c|c|c|c|c|c|}
\hline \multicolumn{6}{|c|}{ LIC Sample } \\
\hline & \multicolumn{2}{|c|}{ Correct (in \%) } & \multicolumn{2}{|c|}{ Incorrect (in \%) } & \multirow[b]{2}{*}{$\begin{array}{c}\text { Chi Square } \\
\text { Value }\end{array}$} \\
\hline & $\begin{array}{c}\text { Forecast }>0 \\
\text { Actual }>0\end{array}$ & $\begin{array}{c}\text { Forecast } \leq \mathbf{0} \\
\text { Actual } \leq \mathbf{0}\end{array}$ & $\begin{array}{c}\text { Forecast }>0 \\
\text { Actual } \leq \mathbf{0}\end{array}$ & $\begin{array}{c}\text { Forecast } \leq \mathbf{0} \\
\text { Actual }>\mathbf{0}\end{array}$ & \\
\hline Current Account Growth & 40.7 & 23.3 & 24.4 & 11.6 & $5.544 * *$ \\
\hline Goods Import Growth & 74.4 & 14.0 & 8.1 & 3.5 & $31.439 * * *$ \\
\hline Goods Export Growth & 77.9 & 7.0 & 8.1 & 7.0 & $10.255^{* * *}$ \\
\hline Services Import Growth & 69.8 & 9.3 & 14.0 & 7.0 & $8.611^{* * *}$ \\
\hline Services Export Growth & 70.9 & 8.1 & 14.0 & 7.0 & $6.930 * * *$ \\
\hline Net Transfers Growth & 46.5 & 15.1 & 17.4 & 20.9 & 1.331 \\
\hline Net Income Growth & 34.9 & 25.6 & 18.6 & 20.9 & $2.774 *$ \\
\hline
\end{tabular}

\begin{tabular}{|c|c|c|c|c|c|}
\hline \multicolumn{6}{|c|}{ Non-LIC Sample } \\
\hline & \multicolumn{2}{|c|}{ Correct (in \%) } & \multicolumn{2}{|c|}{ Incorrect (in \%) } & \multirow[b]{2}{*}{$\begin{array}{c}\text { Chi Square } \\
\text { Value }\end{array}$} \\
\hline & $\begin{array}{c}\text { Forecast }>0 \\
\text { Actual }>0\end{array}$ & $\begin{array}{c}\text { Forecast } \leq \mathbf{0} \\
\text { Actual } \leq \mathbf{0}\end{array}$ & $\begin{array}{c}\text { Forecast }>\mathbf{0} \\
\text { Actual } \leq \mathbf{0}\end{array}$ & $\begin{array}{c}\text { Forecast } \leq \mathbf{0} \\
\text { Actual }>\mathbf{0}\end{array}$ & \\
\hline Current Account Growth & 21.7 & 54.3 & 10.9 & 13.0 & $7.998^{* * *}$ \\
\hline Goods Import Growth & 52.2 & 30.4 & 13.0 & 4.3 & $16.697 * * *$ \\
\hline Goods Export Growth & 65.2 & 21.7 & 6.5 & 6.5 & $17.952 * * *$ \\
\hline Services Import Growth & 54.3 & 23.9 & 10.9 & 10.9 & $10.288 * * *$ \\
\hline Services Export Growth & 67.4 & 19.6 & 6.5 & 6.5 & $16.859 * * *$ \\
\hline Net Transfers Growth & 50.0 & 13.0 & 6.5 & 30.4 & 1.416 \\
\hline Net Income Growth & 32.6 & 19.6 & 26.1 & 21.7 & 0.038 \\
\hline
\end{tabular}

Notes: $* * *, * *$ and * indicate 1,5 and 10 percent level of statistical significance, respectively. 
Table 5b: Correct and Incorrect Forecasts of Financial Account and Its Subcomponent Growth Rates

\begin{tabular}{|l|c|c|c|c|c|}
\hline \multirow{2}{*}{} & \multicolumn{2}{|c|}{ Correct } & \multicolumn{2}{c|}{ Incorrect } & \multirow{2}{*}{$\begin{array}{c}\text { Chil Sample } \\
\end{array}$} \\
\cline { 2 - 6 } & $\begin{array}{c}\text { Forecast }>\mathbf{0} \\
\text { Actual }>\mathbf{0}\end{array}$ & $\begin{array}{c}\text { Forecast } \leq \mathbf{0} \\
\text { Actual } \leq \mathbf{0}\end{array}$ & $\begin{array}{c}\text { Forecast }>\mathbf{0} \\
\text { Actual } \leq \mathbf{0}\end{array}$ & $\begin{array}{c}\text { Forecast } \leq \mathbf{0} \\
\text { Actual }>\mathbf{0}\end{array}$ & $\begin{array}{c}\text { Chalue } \\
\text { Value }\end{array}$ \\
\hline Financial Account Growth & 23.0 & 42.6 & 13.1 & 21.3 & $4.079^{* *}$ \\
Net Direct Investment & 39.3 & 26.2 & 18.0 & 16.4 & $4.330^{* *}$ \\
Reserve Assets & 14.8 & 52.5 & 14.8 & 18.0 & 2.415 \\
Other Investment & 14.8 & 44.3 & 19.7 & 21.3 & 0.270 \\
Net Portfolio Investment & 16.4 & 47.5 & 14.8 & 21.3 & 1.776 \\
\hline
\end{tabular}

\begin{tabular}{|c|c|c|c|c|c|}
\hline \multicolumn{6}{|c|}{ LIC Sample } \\
\hline & \multicolumn{2}{|c|}{ Correct } & \multicolumn{2}{|c|}{ Incorrect } & \multirow[b]{2}{*}{$\begin{array}{c}\text { Chi Square } \\
\text { Value }\end{array}$} \\
\hline & $\begin{array}{c}\text { Forecast }>0 \\
\text { Actual }>0\end{array}$ & $\begin{array}{c}\text { Forecast } \leq \mathbf{0} \\
\text { Actual } \leq \mathbf{0}\end{array}$ & $\begin{array}{c}\text { Forecast }>0 \\
\text { Actual } \leq 0\end{array}$ & $\begin{array}{c}\text { Forecast } \leq \mathbf{0} \\
\text { Actual }>\mathbf{0}\end{array}$ & \\
\hline Financial Account Growth & 23.5 & 35.3 & 17.6 & 23.5 & 0.405 \\
\hline Net Direct Investment & 47.1 & 17.6 & 17.6 & 17.6 & 0.902 \\
\hline Reserve Assets & 14.7 & 52.9 & 14.7 & 17.6 & 1.035 \\
\hline Other Investment & 17.6 & 41.2 & 17.6 & 23.5 & 0.166 \\
\hline Net Portfolio Investment & 23.5 & 38.2 & 20.6 & 17.6 & 0.863 \\
\hline
\end{tabular}

\begin{tabular}{|c|c|c|c|c|c|}
\hline \multicolumn{6}{|c|}{ Non-LIC Sample } \\
\hline & \multicolumn{2}{|c|}{ Correct } & \multicolumn{2}{|c|}{ Incorrect } & \multirow[b]{2}{*}{$\begin{array}{c}\text { Chi Square } \\
\text { Value }\end{array}$} \\
\hline & $\begin{array}{c}\text { Forecast }>0 \\
\text { Actual }>0\end{array}$ & $\begin{array}{c}\text { Forecast } \leq \mathbf{0} \\
\text { Actual } \leq \mathbf{0}\end{array}$ & $\begin{array}{c}\text { Forecast }>0 \\
\text { Actual } \leq 0\end{array}$ & $\begin{array}{c}\text { Forecast } \leq \mathbf{0} \\
\text { Actual }>\mathbf{0}\end{array}$ & \\
\hline Financial Account Growth & 22.2 & 51.9 & 7.4 & 18.5 & $3.694 *$ \\
\hline Net Direct Investment & 29.6 & 37.0 & 18.5 & 14.8 & 1.782 \\
\hline Reserve Assets & 14.8 & 51.9 & 14.8 & 18.5 & 0.555 \\
\hline Other Investment & 11.1 & 48.1 & 22.2 & 18.5 & 0.089 \\
\hline Net Portfolio Investment & 7.4 & 59.3 & 7.4 & 25.9 & 0.037 \\
\hline
\end{tabular}

Notes: ***,** and * indicate 1,5 and 10 percent level of statistical significance, respectively.

Table 6: Contributors to Balance of Payments Forecast Errors

\begin{tabular}{|l|c|c|c|}
\hline \multicolumn{3}{|c|}{ Panel A: Current Account Balance } \\
\hline $\begin{array}{l}\text { Dep. variable: CA growth } \\
\text { (Forecast Error, FE) }\end{array}$ & All & LICs & $\begin{array}{c}\text { Non- } \\
\text { LICs }\end{array}$ \\
\hline Goods Import Growth & $2.178^{* * *}$ & 1.555 & $3.199^{* * *}$ \\
(FE) & $(0.829)$ & $(0.992)$ & $(0.999)$ \\
Goods Export Growth & -0.664 & -0.373 & -1.342 \\
(FE) & $(0.542)$ & $(0.773)$ & $(0.952)$ \\
Services Import Growth & -0.254 & -0.709 & 0.928 \\
(FE) & $(0.748)$ & $(1.254)$ & $(0.953)$ \\
Services Export Growth & -0.657 & -0.656 & -0.366 \\
(FE) & $(0.527)$ & $(0.661)$ & $(0.620)$ \\
Net Transfers Growth & 0.133 & 0.412 & 0.181 \\
(FE) & $(0.491)$ & $(1.027)$ & $(0.167)$ \\
Net Income Growth & 0.005 & -0.023 & $-0.337 * *$ \\
(FE) & $(0.082)$ & $(0.124)$ & $(0.151)$ \\
Constant & 0.066 & -0.009 & $0.243 * *$ \\
& $(0.155)$ & $(0.185)$ & $(0.118)$ \\
\hline \hline Observations & 132 & 86 & 46 \\
R-squared & 0.056 & 0.050 & 0.236 \\
\hline
\end{tabular}

\begin{tabular}{|l|c|c|c|}
\hline \multicolumn{4}{|c|}{ Panel B: Financial Account Balance } \\
\hline $\begin{array}{l}\text { Dep. variable: FA growth } \\
\text { (Forecast Error, FE) }\end{array}$ & $\mathbf{6 d}$ & $\mathbf{6 e}$ & $\begin{array}{c}\text { 6f } \\
\text { Non- } \\
\text { LICs }\end{array}$ \\
\hline Net Direct Investment Growth & 0.299 & 0.316 & 0.202 \\
(FE) & $(0.386)$ & $(0.505)$ & $(0.570)$ \\
Reserve Assets Growth & 0.001 & -0.094 & 0.069 \\
(FE) & $(0.046)$ & $(0.061)$ & $(0.050)$ \\
Other Investment Growth & -0.011 & -0.014 & -0.005 \\
(FE) & $(0.008)$ & $(0.014)$ & $(0.011)$ \\
Net Portfolio Investment Growth & 0.008 & -0.026 & 0.027 \\
(FE) & $(0.062)$ & $(0.095)$ & $(0.105)$ \\
Constant & -0.298 & -0.323 & -0.219 \\
& $(0.311)$ & $(0.423)$ & $(0.494)$ \\
\hline \hline Observations & 61 & 34 & 27 \\
R-squared & 0.030 & 0.079 & 0.061 \\
\hline
\end{tabular}

Notes: All variables are forecast errors of growth rates. Robust standard errors in parenthesis. ***, ** and * indicate 1,5 and 10 percent level of statistical significance, respectively. 


\section{Table 7a: Mincer-Zarnowitz Regressions - Government Expenditure Growth}

\begin{tabular}{|lcccc|}
\multicolumn{5}{c}{ Full Sample } \\
\begin{tabular}{|lccc} 
Dependent variable: \\
Actual growth rate
\end{tabular} & Gov. Exp. & $\begin{array}{c}\text { Interest } \\
\text { Exp. }\end{array}$ & $\begin{array}{c}\text { Non-interest } \\
\text { Exp. }\end{array}$ & $\begin{array}{c}\text { Cap. Exp. \& } \\
\text { Net Lending }\end{array}$ \\
\hline Forecast growth rate, $\boldsymbol{\beta}$ & 0.744 & 0.778 & 0.922 & 0.513 \\
& $(0.183)$ & $(0.008)$ & $(0.176)$ & $(0.227)$ \\
Constant, $\boldsymbol{\alpha}$ & 0.083 & 0.029 & 0.102 & 0.166 \\
& $(0.034)$ & $(0.018)$ & $(0.088)$ & $(0.127)$ \\
Crisis08 & -0.042 & 0.039 & 0.025 & -0.082 \\
& $(0.037)$ & $(0.130)$ & $(0.043)$ & $(0.077)$ \\
Africa & -0.068 & -0.117 & -0.089 & -0.124 \\
& $(0.042)$ & $(0.080)$ & $(0.092)$ & $(0.127)$ \\
America & -0.074 & -0.093 & -0.125 & -0.095 \\
& $(0.046)$ & $(0.054)$ & $(0.089)$ & $(0.162)$ \\
Asia & -0.042 & 0.077 & -0.068 & -0.173 \\
& $(0.052)$ & $(0.068)$ & $(0.091)$ & $(0.146)$ \\
\hline \hline Observations & 34 & 34 & 34 & 34 \\
R-squared & 0.451 & 0.979 & 0.595 & 0.252 \\
\hline F-test $\boldsymbol{\alpha}=\mathbf{0 ,} \boldsymbol{\beta}=\mathbf{1 )}$ & 3.094 & $405.400^{* * *}$ & 0.747 & 2.322 \\
Holden-Peel t-test & $2.078^{* *}$ & -0.753 & 1.143 & 0.500 \\
\hline
\end{tabular}

\begin{tabular}{|c|c|c|c|c|}
\hline \multicolumn{5}{|c|}{ LIC Sample } \\
\hline $\begin{array}{l}\text { Dependent variable: } \\
\text { Actual growth rate }\end{array}$ & Gov. Exp. & $\begin{array}{l}\text { Interest } \\
\text { Exp. }\end{array}$ & $\begin{array}{l}\text { Non-interest } \\
\text { Exp. }\end{array}$ & $\begin{array}{l}\text { Cap. Exp. \& } \\
\text { Net Lending } \\
\end{array}$ \\
\hline \multirow[t]{2}{*}{ Forecast growth rate, $\beta$} & 0.739 & 0.786 & 0.941 & 0.375 \\
\hline & $(0.180)$ & $(0.006)$ & $(0.194)$ & $(0.226)$ \\
\hline \multirow[t]{2}{*}{ Constant, $\alpha$} & 0.047 & 0.020 & 0.016 & 0.139 \\
\hline & $(0.046)$ & $(0.037)$ & $(0.039)$ & $(0.103)$ \\
\hline \multirow[t]{2}{*}{ Crisis08 } & -0.042 & 0.041 & 0.024 & -0.101 \\
\hline & $(0.037)$ & $(0.129)$ & $(0.042)$ & $(0.076)$ \\
\hline \multirow[t]{2}{*}{ Africa } & -0.030 & -0.110 & -0.004 & -0.072 \\
\hline & $(0.042)$ & $(0.087)$ & $(0.029)$ & $(0.098)$ \\
\hline \multirow[t]{2}{*}{ America } & -0.020 & -0.087 & -0.033 & 0.018 \\
\hline & $(0.053)$ & $(0.074)$ & $(0.043)$ & $(0.132)$ \\
\hline Asia & \multicolumn{4}{|c|}{ Omitted due to collinearity } \\
\hline Observations & 29 & 29 & 29 & 29 \\
\hline R-squared & 0.463 & 0.980 & 0.640 & 0.219 \\
\hline F-test $(\alpha=0, \beta=1)$ & 2.108 & $914.400 * * *$ & 0.110 & $5.447 * *$ \\
\hline Holden-Peel t-test & -1.035 & -1.175 & 0.393 & -0.785 \\
\hline
\end{tabular}

Notes: Robust standard errors in parentheses. No significance values reported for individual coefficient estimates. $* * *, * *$ and $*$ indicate rejection of the null hypothesis of the Mincer-Zarnowitz F-test and the Holden-Peel t-test at the 10,5 and 1 percent level of statistical significance, respectively. 
Table 7b: Mincer-Zarnowitz Regressions - Government Revenue Growth

\begin{tabular}{|lcccc|}
\multicolumn{5}{c}{ Full Sample } \\
$\begin{array}{|lccc|}\text { Dependent variable: } \\
\text { Actual growth rate }\end{array}$ & $\begin{array}{c}\text { Gov. } \\
\text { Revenue }\end{array}$ & Grants & $\begin{array}{c}\text { Tax } \\
\text { Revenue }\end{array}$ & $\begin{array}{c}\text { Non-tax } \\
\text { Revenue }\end{array}$ \\
\hline Forecast growth rate, $\boldsymbol{\beta}$ & 0.866 & 0.798 & 0.817 & 0.363 \\
Constant, $\boldsymbol{\alpha}$ & $(0.083)$ & $(0.036)$ & $(0.120)$ & $(0.077)$ \\
& 0.008 & -0.092 & 0.014 & 0.032 \\
Crisis08 & $(0.023)$ & $(0.351)$ & $(0.021)$ & $(0.081)$ \\
& 0.064 & 0.429 & 0.013 & 0.166 \\
Africa & $(0.057)$ & $(0.368)$ & $(0.029)$ & $(0.159)$ \\
& 0.026 & 0.043 & 0.037 & 0.136 \\
America & $(0.030)$ & $(0.362)$ & $(0.027)$ & $(0.104)$ \\
& 0.020 & 0.216 & 0.011 & 0.081 \\
Asia & $(0.029)$ & $(0.366)$ & $(0.024)$ & $(0.106)$ \\
& 0.012 & 0.063 & 0.023 & 0.161 \\
\hline \hline Observations & $(0.027)$ & $(0.355)$ & $(0.036)$ & $(0.127)$ \\
R-squared & 69 & 69 & 69 & 69 \\
\hline F-test $(\boldsymbol{\alpha}=\mathbf{0}, \boldsymbol{\beta}=\mathbf{1})$ & 0.775 & 0.899 & 0.622 & 0.242 \\
Holden-Peel t-test & 1.345 & $15.860 * * *$ & 1.184 & $35.610^{* * *}$ \\
\hline
\end{tabular}

\begin{tabular}{|lcccc|}
\multicolumn{5}{c}{ LIC Sample } \\
\begin{tabular}{|l} 
Dependent variable: \\
Actual growth rate
\end{tabular} & $\begin{array}{c}\text { Gov. } \\
\text { Revenue }\end{array}$ & Grants & $\begin{array}{c}\text { Tax } \\
\text { Revenue }\end{array}$ & $\begin{array}{c}\text { Non-tax } \\
\text { Revenue }\end{array}$ \\
\hline Forecast growth rate, $\boldsymbol{\beta}$ & 0.840 & 0.804 & 0.742 & 0.307 \\
Constant, $\boldsymbol{\alpha}$ & $(0.104)$ & $(0.031)$ & $(0.147)$ & $(0.066)$ \\
& 0.071 & -0.145 & 0.078 & 0.214 \\
Crisis08 & $(0.019)$ & $(0.061)$ & $(0.019)$ & $(0.065)$ \\
& 0.067 & 0.390 & 0.013 & 0.200 \\
Africa & $(0.058)$ & $(0.372)$ & $(0.029)$ & $(0.151)$ \\
& -0.037 & 0.131 & -0.019 & -0.065 \\
America & $(0.028)$ & $(0.108)$ & $(0.020)$ & $(0.091)$ \\
& -0.048 & 0.166 & -0.034 & -0.061 \\
Asia & $(0.029)$ & $(0.133)$ & $(0.024)$ & $(0.100)$ \\
& -0.032 & 0.142 & -0.009 & 0.040 \\
& $(0.024)$ & $(0.085)$ & $(0.039)$ & $(0.128)$ \\
\hline \hline Observations & 57 & 57 & 57 & 57 \\
R-squared & 0.759 & 0.924 & 0.534 & 0.217 \\
\hline F-test $(\boldsymbol{\alpha}=\mathbf{0}, \boldsymbol{\beta}=\mathbf{1})$ & $7.625 * * *$ & $23.540^{* * *}$ & $34.880^{* * *}$ & $63.100^{* * *}$ \\
Holden-Peel t-test & $4.360^{* * *}$ & $-2.828 * * *$ & $32.970 * * *$ & $3.685 * * *$ \\
\hline
\end{tabular}

Notes: Robust standard errors in parentheses. No significance values reported for individual coefficient estimates. $* * *, * *$ and $*$ indicate rejection of the null hypothesis of the MincerZarnowitz F-test and the Holden-Peel t-test at the 10, 5 and 1 percent level of statistical significance, respectively. 
Table 8a: Correct and Incorrect Forecasts of Gov. Expenditure and Its Subcomponent Growth Rates

\begin{tabular}{|c|c|c|c|c|c|}
\hline \multicolumn{6}{|c|}{ Full Sample } \\
\hline & \multicolumn{2}{|c|}{ Correct (in \%) } & \multicolumn{2}{|c|}{ Incorrect (in \%) } & \multirow[b]{2}{*}{$\begin{array}{c}\text { Chi Square } \\
\text { Value }\end{array}$} \\
\hline & $\begin{array}{c}\text { Forecast }>0 \\
\text { Actual }>0\end{array}$ & $\begin{array}{c}\text { Forecast } \leq 0 \\
\text { Actual } \leq 0\end{array}$ & $\begin{array}{c}\text { Forecast }>0 \\
\text { Actual } \leq 0\end{array}$ & $\begin{array}{c}\text { Forecast } \leq 0 \\
\text { Actual }>0\end{array}$ & \\
\hline Gov. Expenditure Growth & 79.4 & 5.9 & 11.8 & 2.9 & 2.370 \\
\hline Interest Expenditure Growth & 70.6 & 8.8 & 17.6 & 2.9 & $3.023^{*}$ \\
\hline Non-interest Expenditure Growth & 76.5 & 11.8 & 8.8 & 2.9 & $8.754 * * *$ \\
\hline Cap. Expenditure \& Net Lending Growth & 70.6 & 11.8 & 14.7 & 2.9 & $5.707 * *$ \\
\hline
\end{tabular}

\begin{tabular}{|c|c|c|c|c|c|}
\hline \multicolumn{6}{|c|}{ LIC Sample } \\
\hline & \multicolumn{2}{|c|}{ Correct (in \%) } & \multicolumn{2}{|c|}{ Incorrect (in \%) } & \multirow[b]{2}{*}{$\begin{array}{c}\text { Chi Square } \\
\text { Value }\end{array}$} \\
\hline & $\begin{array}{c}\text { Forecast }>0 \\
\text { Actual }>0\end{array}$ & $\begin{array}{c}\text { Forecast } \leq \mathbf{0} \\
\text { Actual } \leq \mathbf{0}\end{array}$ & $\begin{array}{c}\text { Forecast }>0 \\
\text { Actual } \leq \mathbf{0}\end{array}$ & $\begin{array}{c}\text { Forecast } \leq \mathbf{0} \\
\text { Actual }>\mathbf{0}\end{array}$ & \\
\hline Gov. Expenditure Growth & 79.3 & 6.9 & 10.3 & 3.4 & 2.517 \\
\hline Interest Expenditure Growth & 69.0 & 10.3 & 17.2 & 3.4 & $2.831 *$ \\
\hline Non-interest Expenditure Growth & 72.4 & 13.8 & 10.3 & 3.4 & $6.940 * * *$ \\
\hline Cap. Expenditure \& Net Lending Growth & 75.9 & 10.3 & 10.3 & 3.4 & $4.943 * *$ \\
\hline
\end{tabular}

Notes: $* * *, * *$ and $*$ indicate 1,5 and 10 percent level of statistical significance, respectively.

Table 8b: Correct and Incorrect Forecasts of Gov. Revenue and Its Subcomponent Growth Rates

\begin{tabular}{|c|c|c|c|c|c|}
\hline \multicolumn{6}{|c|}{ Full Sample } \\
\hline & \multicolumn{2}{|c|}{ Correct (in \%) } & \multicolumn{2}{|c|}{ Incorrect (in \%) } & \multirow[b]{2}{*}{ Chi Square Value } \\
\hline & $\begin{array}{c}\text { Forecast }>0 \\
\text { Actual }>0\end{array}$ & $\begin{array}{c}\text { Forecast } \leq 0 \\
\text { Actual } \leq 0\end{array}$ & $\begin{array}{c}\text { Forecast }>0 \\
\text { Actual } \leq 0\end{array}$ & $\begin{array}{c}\text { Forecast } \leq 0 \\
\text { Actual }>0\end{array}$ & \\
\hline $\begin{array}{l}\text { Gov. Revenue Growth } \\
\text { Grants Growth } \\
\text { Tax Revenue Growth } \\
\text { Non-tax Revenue Growth } \\
\end{array}$ & $\begin{array}{l}81.2 \\
52.2 \\
85.5 \\
62.3 \\
\end{array}$ & $\begin{array}{c}7.2 \\
15.9 \\
8.7 \\
15.9 \\
\end{array}$ & $\begin{array}{c}5.8 \\
24.6 \\
1.4 \\
5.8 \\
\end{array}$ & $\begin{array}{c}5.8 \\
7.2 \\
4.3 \\
15.9 \\
\end{array}$ & $\begin{array}{c}12.463 * * * \\
5.419 * * \\
29.493 * * * \\
12.821 * * * \\
\end{array}$ \\
\hline \multicolumn{6}{|c|}{ LIC Sample } \\
\hline & \multicolumn{2}{|c|}{ Correct (in \%) } & \multicolumn{2}{|c|}{ Incorrect (in \%) } & \\
\hline & $\begin{array}{c}\text { Forecast }>0 \\
\text { Actual }>0\end{array}$ & $\begin{array}{c}\text { Forecast } \leq 0 \\
\text { Actual } \leq 0\end{array}$ & $\begin{array}{c}\text { Forecast }>0 \\
\text { Actual } \leq 0\end{array}$ & $\begin{array}{c}\text { Forecast } \leq 0 \\
\text { Actual }>0\end{array}$ & Chi Square Value \\
\hline $\begin{array}{l}\text { Gov. Revenue Growth } \\
\text { Grants Growth } \\
\text { Tax Revenue Growth } \\
\text { Non-tax Revenue Growth }\end{array}$ & $\begin{array}{l}82.5 \\
52.6 \\
87.7 \\
64.9\end{array}$ & $\begin{array}{c}5.3 \\
15.8 \\
7.0 \\
12.3\end{array}$ & $\begin{array}{c}7.0 \\
24.6 \\
1.8 \\
5.3\end{array}$ & $\begin{array}{c}5.3 \\
7.0 \\
3.5 \\
17.5\end{array}$ & $\begin{array}{c}5.475 * * \\
4.385 * * \\
20.584 * * * \\
7.170 * * *\end{array}$ \\
\hline
\end{tabular}

Notes: $* * * * *$ and $*$ indicate 1,5 and 10 percent level of statistical significance, respectively.

\section{Table 9: Contributors to Government Budget Growth Forecast Errors}

\begin{tabular}{|l|c|c|}
\hline \multicolumn{3}{|c|}{ Panel A: Government Expenditure } \\
\hline Dep. variable: Gov. exp. growth & 9a & 9b \\
(Forecast Error, FE) & All & LICs \\
\hline Interest Expenditure Growth & 0.003 & 0.000 \\
(FE) & $(0.008)$ & $(0.008)$ \\
Non-interest Expenditure Growth & $0.644^{* * *}$ & $0.667^{* * *}$ \\
(FE) & $(0.066)$ & $(0.082)$ \\
Cap. Exp. \& Lending Growth & $0.254^{* * *}$ & $0.251^{* * *}$ \\
(FE) & $(0.020)$ & $(0.021)$ \\
Constant & 0.008 & 0.011 \\
& $(0.007)$ & $(0.008)$ \\
\hline \hline Observations & 34 & 29 \\
R-squared & 0.895 & 0.891 \\
\hline
\end{tabular}

\begin{tabular}{|l|c|c|}
\hline \multicolumn{3}{|c|}{ Panel B: Government Revenue } \\
\hline Dep. variable: Gov. rev. growth & 9c & 9d \\
(Forecast Error, FE) & All & LICs \\
\hline Grants Growth & $0.069^{* * *}$ & $0.082^{* *}$ \\
(FE) & $(0.024)$ & $(0.033)$ \\
Tax Revenue Growth & $0.529^{*}$ & $0.513^{*}$ \\
(FE) & $(0.274)$ & $(0.288)$ \\
Non-tax Revenue Growth & $0.045^{*}$ & 0.043 \\
(FE) & $(0.025)$ & $(0.028)$ \\
Constant & -0.007 & -0.008 \\
& $(0.010)$ & $(0.012)$ \\
\hline \hline Observations & 69 & 57 \\
R-squared & 0.415 & 0.422 \\
\hline
\end{tabular}

Notes: All variables are forecast errors of growth rates. Robust standard errors in parenthesis. ${ }^{* * *},{ }^{* *}$ and $*$ indicate 1,5 and 10 percent level of statistical significance, respectively. 


\section{Appendix}

\section{Table A1: Programs in Broadest Global Sample}

\begin{tabular}{|c|c|c|c|c|c|}
\hline Country/Program & Date & Country/Program & Date & Country/Program & Date \\
\hline Afghanistan & June 2006 & Georgia & April 2012 & Nigeria & October 2005 \\
\hline Afghanistan & November 2011 & Georgia & July 2014 & Pakistan & September 2013 \\
\hline Albania & June 2002 & Ghana & May 2003 & Paraguay & December 2003 \\
\hline Albania & January 2006 & Ghana & July 2009 & Paraguay & May 2006 \\
\hline Angola & November 2009 & Ghana & April 2015 & Peru & June 2004 \\
\hline Antigua and Barbuda & June 2010 & Greece & May 2010 & Peru & January 2007 \\
\hline Argentina & September 2003 & Greece & March 2012 & Portugal & May 2011 \\
\hline Armenia & May 2005 & Grenada & April 2006 & Romania & July 2004 \\
\hline Armenia & March 2009 & Grenada & April 2010 & Romania & May 2009 \\
\hline Armenia & June 2010 & Grenada & June 2014 & Romania & September 2013 \\
\hline Armenia & March 2014 & Guinea & December 2007 & Rwanda & August 2002 \\
\hline Bangladesh & June 2003 & Guinea & February 2012 & Rwanda & June 2006 \\
\hline Bangladesh & April 2012 & Guinea-Bissau & May 2010 & Sao Tome and Principe & August 2005 \\
\hline Benin & August 2005 & Haiti & July 2010 & Sao Tome and Principe & July 2012 \\
\hline Benin & June 2010 & Honduras & February 2004 & Sao Tome and Principe & July 2015 \\
\hline Bolivia & April 2003 & Honduras & December 2014 & Senegal & April 2003 \\
\hline Bosnia-Herzegovina & July 2009 & Iraq & February 2010 & Senegal & November 2007 \\
\hline Bosnia-Herzegovina & September 2012 & Jordan & July 2002 & Senegal & December 2010 \\
\hline Brazil & September 2002 & Kenya & November 2003 & Senegal & June 2015 \\
\hline Bulgaria & August 2004 & Kenya & January 2011 & Serbia & January 2009 \\
\hline Burkina Faso & June 2003 & Kosovo & April 2012 & Seychelles & November 2008 \\
\hline Burkina Faso & April 2007 & Kosovo & July 2015 & Seychelles & December 2009 \\
\hline Burkina Faso & June 2010 & Kyrgyzstan & February 2005 & Seychelles & June 2014 \\
\hline Burkina Faso & December 2013 & Kyrgyzstan & June 2011 & Sierra Leone & September 2001 \\
\hline Burundi & January 2004 & Kyrgyzstan & April 2015 & Sierra Leone & May 2006 \\
\hline Burundi & July 2008 & Latvia & December 2008 & Sierra Leone & June 2010 \\
\hline Burundi & January 2012 & Lesotho & June 2010 & Solomon Islands & June 2010 \\
\hline Cameroon & October 2005 & Liberia & March 2008 & Solomon Islands & December 2012 \\
\hline Cape Verde & April 2002 & Liberia & November 2012 & Sri Lanka & July 2009 \\
\hline Cape Verde & July 2006 & Macedonia & August 2005 & St. Kitts and Nevis & July 2011 \\
\hline Central Afr. Republic & December 2006 & Macedonia & January 2011 & Tajikistan & December 2002 \\
\hline Chad & August 2014 & Madagascar & July 2006 & Tanzania & March 2000 \\
\hline Colombia & January 2003 & Malawi & August 2005 & Tanzania & August 2003 \\
\hline Colombia & April 2005 & Malawi & February 2010 & Tanzania & February 2007 \\
\hline Comoros & September 2009 & Maldives & December 2009 & Tanzania & June 2010 \\
\hline Republic of Congo & December 2004 & Mali & June 2004 & Tanzania & July 2012 \\
\hline Republic of Congo & December 2008 & Mali & May 2008 & Tanzania & July 2014 \\
\hline Dem. Rep. of Congo & December 2009 & Mali & December 2013 & Togo & April 2008 \\
\hline Cote d'Ivoire & March 2009 & Mauritania & December 2006 & Tunisia & June 2013 \\
\hline Cote d'Ivoire & November 2011 & Mauritania & March 2010 & Turkey & May 2005 \\
\hline Croatia & August 2004 & Moldova & January 2010 & Uganda & September 2002 \\
\hline Cyprus & May 2013 & Mongolia & April 2009 & Uganda & December 2006 \\
\hline Djibouti & September 2008 & Morocco & August 2012 & Uganda & May 2010 \\
\hline Dominica & December 2003 & Mozambique & July 2004 & Uganda & June 2013 \\
\hline Dominican Republic & August 2003 & Mozambique & June 2007 & Ukraine & November 2008 \\
\hline Dominican Republic & January 2005 & Mozambique & June 2010 & Ukraine & July 2010 \\
\hline Dominican Republic & November 2009 & Mozambique & June 2013 & Ukraine & April 2014 \\
\hline El Salvador & March 2010 & Nepal & November 2003 & Ukraine & March 2015 \\
\hline Gabon & May 2007 & Nicaragua & October 2007 & Uruguay & April 2002 \\
\hline The Gambia & February 2007 & Niger & January 2005 & Uruguay & June 2005 \\
\hline The Gambia & May 2012 & Niger & May 2008 & Zambia & June 2004 \\
\hline Georgia & June 2004 & Niger & March 2012 & Zambia & June 2008 \\
\hline
\end{tabular}

